\title{
Integrated Gasification Combined Cycle and Steam Injection Gas Turbine Powered by Biomass Joint- Venture Evaluation
}

George J. Sterzinger

Economics, Environment and Regulation Washington, DC 20036

NREL technical monitor: Ralph Overend

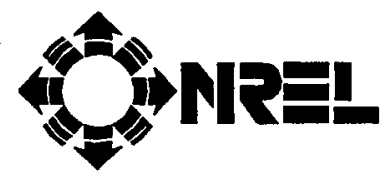

National Renewable Energy Laboratory 1617 Cole Boulevard Golden, Colorado 80401-3393

A national laboratory of the U.S. Department of Energy Operated by Midwest Research Institute for the U.S. Department of Energy Under Contract No. DE-AC02-83CH10093

Under Subcontract No. TAE-2-12246-01

May 1994 


\section{NOTICE}

NOTICE: This report was prepared as an account of work sponsored by an agency of the United States government. Neither the United States government nor any agency thereof, nor any of their employees, makes any warranty, express or implied, or assumes any legal liability or responsibility for the accuracy, completeness, or usefulness of any information, apparatus, product, or process disclosed, or represents that its use would not infringe privately owned rights. Reference herein to any specific commercial product, process, or service by trade name, trademark, manufacturer, or otherwise does not necessarily constitute or imply its endorsement, recommendation, or favoring by the United States government or any agency thereof. The views and opinions of authors expressed herein do not necessarily state or reflect those of the United States government or any agency thereof.

Printed in the United States of America

Available from:

National Technical Information Service

U.S. Department of Commerce

5285 Port Royal Road

Springfield, VA 22161

Price: Microfiche A01

Printed Copy A04

Codes are used for pricing all publications. The code is determined by the number of pages in the publication. Information pertaining to the pricing codes can be found in the current issue of the following publications which are generally available in most libraries: Energy Research Abstracts (ERA); Government Reports Announcements and Index (GRA and I); Scientific and Technical Abstract Reports (STAR); and publication NTIS-PR-360 available from NTIS at the above address. 


\section{Table of Contents}

Executive Summary

I. Review of Technology Status: Brazilian/World Bank Project

A. Pre-Development Goals

B. Project Development

C. Turbine Selection

D. Gasifier Technology

E. Phase Two Goal for Gasified/Gas Clean-up Developers

II. DOE: Biomass to Electricity Program

III. Joint Ventures to Advance Technology .

A. Nature of the Proposed Joint Venture

B. Public Participation in Joint Venture Based on

an Expanded Assessment of Competitive Potential

and Environmental Benefits

IV. Project Economics

V. Development Risk

A. Identification and Quantification of Major Areas of

Development Risk.

B. Financial Framework for Project Assessment

C. Incentives Beyond Joint-Venture Financing

VI. Equipment Manufacturers

VII. Site Evaluations

A. Bennington County and State of Vermont

B. State of Iowa 


\section{Executive Summary}

The Department of Energy (DOE) participation in a joint venture to commercially demonstrate biomass integrated gasifier/gas turbine (BIG/GT) technology is feasible and strongly recommenced under the Energy Policy Act of 1992 and Public Law 101.218. The Secretary of Energy is authorized to use federal funds to buy-down the cost of initial projects to demonstrate technologies with significant energy security and environmental benefits. The ability of this technology to compete aggressively for market applications is amply demonstrated by analysis independently conducted as part of this work and corroborated by the World Bank Global Environment Facility (GEF), DOE, and several independent groups including the Electric Power Research Institute (EPRI). Most significantly, the likelihood of market success is attested to by the readiness of private participants to contribute more than half the original project cost.

This report analyzes the economic and environmental potential of the technology. Joint ventures can be thought of as an investment of public funds to achieve public benefits. Given the market potential demonstrated by this technology, the public return is astronomical. The mature technology promises to produce electricity at $\$ 55-60 / \mathrm{MWh}$ and to be competitive for market applications conservatively estimated at $2000 \mathrm{MW}$. Using DOE national average figures for potential avoided $\mathrm{CO}_{2}$ per $\mathrm{kWh}$ from renewable technologies, a successful joint venture to demonstrate this technology would remove $\mathrm{CO}_{2}$ at a cost of $\$ 0.85 /$ ton. This calculation is based on the following assumptions: $\$ 1000 / \mathrm{kW}$ of federal funds are committed to the joint-venture process, leading to a 100-to-1 market-to-demonstration development; this technology produces electricity for 20 years with an annual capacity factor of $75 \%$; and the initial $\$ 1000 / \mathrm{kW}$ is converted to annual payment using a capital recovery factor of $10 \%$.

This project involved a series of discussions and negotiations with states, localities, utilities, and private developers to gauge non-federal commitment to a joint venture. Striving for cost-effectiveness, the project set out to minimize the public risk buy-down of the technology deployment. Site selection and project phasing proved most useful in this respect.

A phased project with gasification development prior to integration with a turbine, at a site with back-up fuel and significant experience in biomass fuel processing, reduces overall project risk by $50 \%$ to $60 \%$. Expectations have been that initial project deployment could require a commitment of between $\$ 20 \mathrm{M}$ and $\$ 30 \mathrm{M}$ in federal funds to buy-down commercial deployment risks (see the World Bank/GEF assessment). Our negotiations indicate that the first phase would require $\$ 5-10 \mathrm{M}$ in federal funds to reduce the risk to a tolerable level for a commercial developer. Once the first phase is completed, turbine integration can be accomplished for, at most, $\$ 3-5 \mathrm{M}$ in federal funds to supplement commercial funds. Follow-on projects can build off of these efforts.

While this report is focused most sharply on the first project, the process envisioned and recommended is very much cooperative, multi-site, and multi-fuel. An initial demonstration and deployment of 15$20 \mathrm{MW}$ of biomass integrated gasifier/gas turbine technology can conservatively be shown to lead to opportunities for $2000 \mathrm{MW}$ of commercial applications if the technology is aggressively demonstrated and deployed for all biomass fuels; e.g., wood waste from forest culls, switchgrass, agricultural wastes, and urban waste woods.

Biomass fuels for electric generation today labor under two disadvantages relative to fossil fuels. First, the fuels compete on a $\$ / B t u$ basis. Biomass has been hurt by steep declines in fossil fuel prices since the mid-1980s. Second, biomass fuels now are limited to combustion steam-turbine technologies, which, for efficiency gain, depend upon increasing plant-size installed capacity (requiring more fuel, transported at greater distance, at increased cost). 
Natural gas faces no such limitation and enjoys an efficiency advantage over steam-turbine generators that approaches $50 \%$ for the size plant that appears feasible for widespread biomass application. Thus, even if biomass fuels could compete on a $\$$ Btu basis, biomass applications would be blocked because the technology for converting biomass to electricity is limited and less efficient than those for natural gas.

The gasification of biomass and its integration with highly efficient aero-derivative turbines removes that disadvantage. The potential for this technology to be competitive is well-established by several independent analyses that are reviewed in this report. The potential for market expansion also appears to be substantial, easily passing the 100-to- 1 market-to-development target used in this report.

Financial and operational risks associated with "first-of-a-kind" technologies are substantial. Experience demonstrates that market participants will not take on these first-of-a-kind risks. Development of this technology is unlikely without public participation to buy-down the risks of establishing the market potential. Federal participation is authorized under PL101-218 and refined and expanded under the Energy Policy Act of 1992.

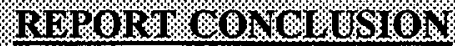

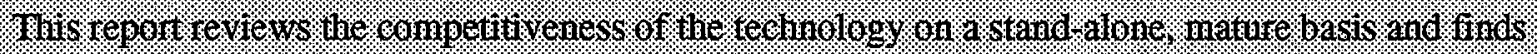

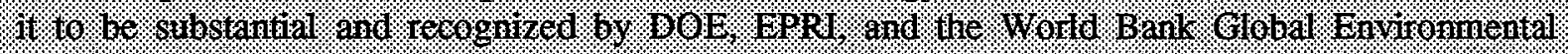
1.8010 .10

To establish the commercial potential of the BIG/GT technology, an assessment should show that the expected cost of electricity produced is equal to or less than the generally accepted avoided cost. It is important to distinguish between the turnkey cost and first plant cost. Turnkey estimates assume the specific risks have been removed and the technology is available at published commercial terms and operating conditions, including performance guarantees.

Several factors dominate the turnkey cost calculation:

- Overall capital cost for turbine, gasifier, gas cleanup, wood yard, and fuel handling equipment

- Fuel cost (green and dry)

- Financial parameters that will be converted and used as capital recovery factors

- Generator conversion efficiency

- Gasifier conversion efficiency

- Gas cleanup cost

The turnkey plant cost estimate developed in Table S-1 shows the levelized cost of production to be $\$ 05.7 / \mathrm{kWh}$. Estimates show the technology to be competitive. This turnkey cost is below the avoided costs for Iowa and Vermont, two states with substantial interest in the technology. While no formal national avoided cost is published, a 1991 estimate set the figure at roughly $\$ 0.7 / \mathrm{kWh}$ [EIA].

For Vermont, a 1991 review estimated the levelized, 20-year avoided cost to be roughly $\$ 0.075 / \mathrm{kWh}$. Since then, lowered demand for electricity has driven down the short-run cost of capacity and has raised questions about the need for capacity in Vermont and the northeast. No utility will state with certainty when the next increment of capacity will be required. Several have indicated the next critical juncture will come in 1998 when a large coal-fired contract is up for renewal. A recent evaluation of long-run 
avoided costs for Vermont conducted for the 1997 time frame showed the 20-year levelized avoided cost to be approximately $\$ 0.8 / \mathrm{kWh}$.

Table S-1. Levelized Long-Run Cost of Electricity from Turnkey Plants

\begin{tabular}{|c|c|}
\hline \multicolumn{2}{|l|}{ Investment Required } \\
\hline Turbine (LM 1600) & $\$ 500 / \mathrm{kW}$ \\
\hline Gasifier and Clean-up & $\$ 430 / \mathrm{kW}^{1}$ \\
\hline Fuel Yard and Handling & $\$ 100 / \mathrm{kW}$ \\
\hline Subtotal & $\$ 1,030 / \mathrm{kW}$ \\
\hline \multicolumn{2}{|l|}{ Fuel Cost } \\
\hline Green Fuel & 2.00/MMBtu \\
\hline Conversion to Gas & $75 \%$ \\
\hline Gasifier Product Cost & 2.67/MMBTU \\
\hline \multicolumn{2}{|l|}{ Cost of Electricity } \\
\hline Capital Recovery & $\$ .01689 / \mathrm{kWh}^{2}$ \\
\hline O\&M & $\$ .0146 / \mathrm{kWh}$ \\
\hline Fuel $^{3}$ & $\$ .02538 / \mathrm{kWh}$ \\
\hline Subtotal & $\$ .05688 / \mathrm{kWh}$ \\
\hline \multicolumn{2}{|c|}{${ }^{1}$ Based on the initial Battelle estimate of $\$ 8.6$ million cost for a $20-\mathrm{MW}_{\text {。 }}$ plant. } \\
\hline $\begin{array}{l}2 \text { Assumes } 71 \% \text { of capacity factor } 0 \\
\text { assumptions used in the DOE asse }\end{array}$ & licate the \\
\hline
\end{tabular}

As a result of the uncertainty, a recommendation for Vermont is that any project be divided into phases, with a gasifier phase done first to reduce reliance on long-run avoided costs. While any long-run avoided cost estimate can serve as a threshold for determining market acceptability, further refinement of the operating characteristics must be developed and supplied to utilities as they make assessments about capacity requirements and resource choices. (See letter from Green Mountain Power (GMP) to EPRI, attached as Appendix 4).

For Iowa, the assessment is straightforward. The state has a law requiring payment of $\$ 0.6 / \mathrm{kWh}$ for electricity from qualifying facilities using renewable resources.

Going back to the estimates of capacity costs for development of turnkey busbar generating costs, most uncertainty is attached to the fuel portion, where it includes not only the cost of biomass but also equipment. Turbine costs and operating characteristics are well-known and subject only to uncertainties about the cost of adapting the turbines to use gas of varying Btu content. As described in the review of the Brazilian project (Section I), technical concerns over modifying the turbine led to some cost, and Phase I funds were diverted for that purpose.

The Brazilian project broke out total capacity costs for the General Electric (GE) LM 1600 with bottoming cycle into fairly detailed investment categories, as shown in Table S-2. 
Roughly two-thirds of total capital costs are related to fuel handling and gasification. Since this is the area of greatest uncertainty with respect to operational characteristics, great attention must be paid to the developmental risk associated with this portion of the technology. Busbar cost estimates are developed as in Table S-3 and show a considerable range. The World Bank project developed estimates (Tables S-4) of the cost of electricity from the first and Nth plant, where the Nth plant represents the estimated potential of the technology on a mature or turnkey basis.

The World Bank and DOE estimates are the most fully developed. The EPRI numbers are initial estimates and subject to updating. They were obtained from a conversation with GMP, which has taken a leading interest in the development of this technology with EPRI.

As the two tables show, the cost of electricity ranges from $\$ 05.4 / \mathrm{kWh}$ to over $\$ 0.10 / \mathrm{kWh}$ (EPRI). The DOE and World Bank estimates are much narrower and are better supported by capital estimates and actual operating characteristics of the turbines. Data on the turbine from the original equipment manufacturer, Stewart and Stephenson, shows that the LM 1600 should have a heat rate of 9,545 Btu/kWh. In addition, the first-time capital estimates of the World Bank/Brazil project are less than

Table S-2. LM 1600/Brazilian Demonstration Plant Investment

\begin{tabular}{lc}
\hline \multicolumn{1}{c}{ Equipment } & Cost Range $(\$ \mathrm{M})$ \\
\hline Wood Yard & 2.4 \\
Gasification Plant & $15.3-21.2$ \\
Turbine & 7.9 \\
Bottoming Cycle & 3.4 \\
TOTAL & $29 .-34.9$ \\
Fuel-Related & $18.6-24.5$ \\
Capacity-Related & 10.4 \\
\hline
\end{tabular}

Source: Brazilian Biomass Power Generation

Table S-3. Brazilian Cost of Electricity Estimates

\begin{tabular}{|c|c|c|c|c|c|}
\hline Altemative & Type of Plant & $\begin{array}{l}\text { Power } \\
\text { Mwe }\end{array}$ & $\begin{array}{c}\text { Total } \\
\text { Investment } \\
\text { US\$ (mill) }\end{array}$ & $\begin{array}{r}\text { IRR } \\
(\%)\end{array}$ & $\begin{array}{c}\text { Energy } \\
\text { Cost } \\
\text { US\$/MWh }\end{array}$ \\
\hline \multirow[t]{2}{*}{ LM 1600} & First-of-Kind & 18 & 49.5 & 8 & 80.2 \\
\hline & Nth Commercial & 18 & 27.0 & 8 & 54.4 \\
\hline \multirow[t]{2}{*}{ LM 2500} & First-of-Kind & 30 & 82.5 & 8 & 80.7 \\
\hline & Nth Commercial & 30 & 45.0 & 8 & 54.8 \\
\hline
\end{tabular}

Source: Brazilian Biomass Power Generation 
Table S-4. Project Economics ${ }^{1}$

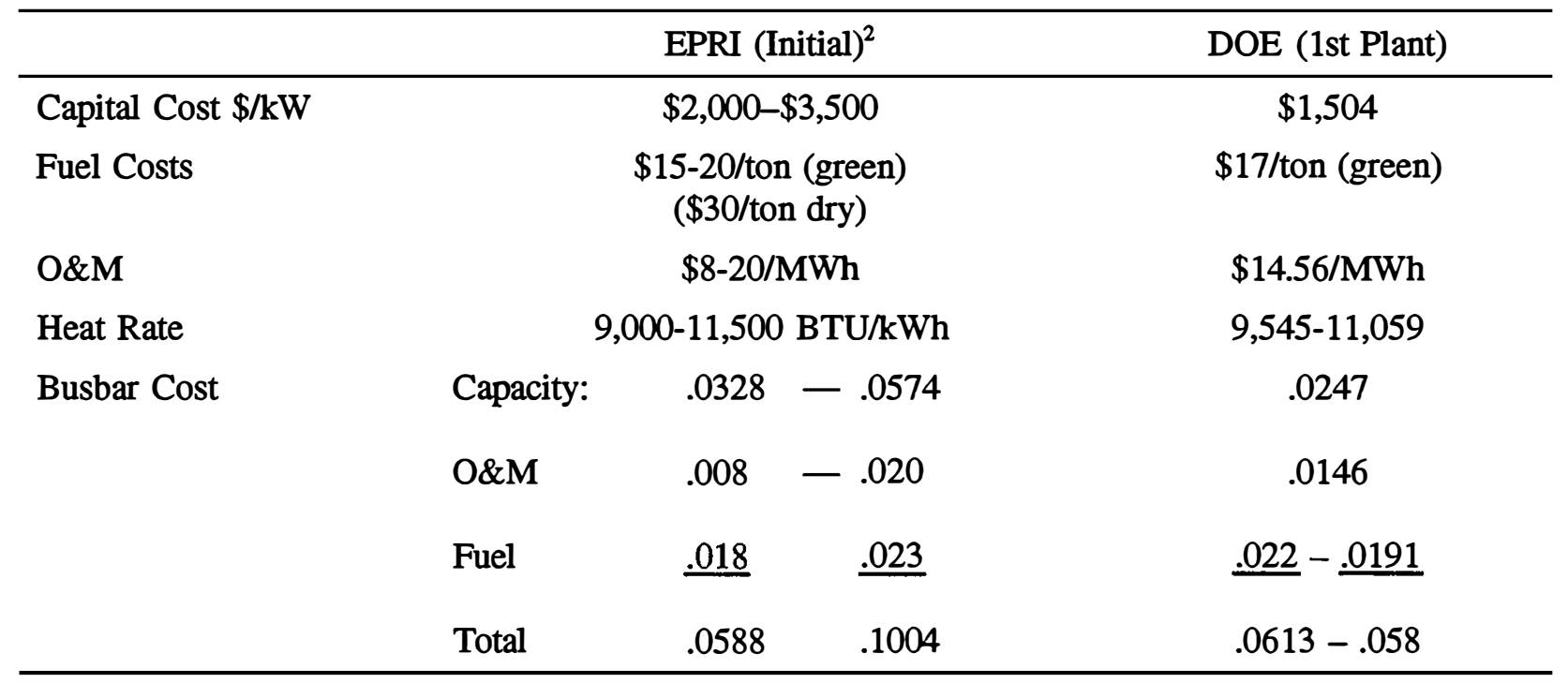

${ }^{1}$ Assume: $71 \%$ capacity factor and $10.2 \%$ CRF.

${ }^{2} \mathrm{EPRI}$ estimates are from conversation with GMP.

the upper estimates supplied by EPRI. Based on the World Bank and DOE estimates, tumkey cost estimates developed for this report of $\$ 05.7 / \mathrm{kWh}$ are reasonable for plants that are fully developed and operational. The conservatism of these estimates is supported by the expectation that the gasifier and cleanup technology can reduce capital costs. For the gasifier, the Future Energy/Battelle process is estimated to cost $\$ 450-600 / \mathrm{kW}_{\mathrm{e}}$, including cleanup cost. If this can be realized, the DOE capital costs would drop $20 \%$ to $30 \%$.

Overall improvements can come from lowering fuel costs, increasing efficiencies, lowering capital costs, and/or reducing carrying costs.

Fuel costs of $\$ 2 / M M B t u$ green wood chips are assumed constant. Any negotiation should attempt to lock in this cost at a constant real-dollar value.

Increases in system efficiencies are available primarily by moving the technology from open-cycle to steam-injected to inter-cooled. Of the two GE turbines, only the LM 1600 can accommodate this development.

System efficiencies are also available by increasing the megawatt size of the project. According to Stewart and Stephenson specifications, the LM 6000, a 42-MW plant in open cycle, has a heat rate of $8300 \mathrm{Btu} / \mathrm{kWh}$, an improvement of nearly $15 \%$ over the LM 1600. Two factors limit the usefulness of this increase, however. As overall efficiency increases the marginal return any improvement in efficiency can make to the bottom line, the busbar generation cost diminishes.

An additional drawback of achieving efficiency by increasing size comes from problems associated with fuel procurement. The larger the plant, the larger the area from which fuel must be gathered. Biomass fuel cost is to some extent a function of travel distance. Larger plants may be expected to have large siting and permitting problems, as they pose greater stress on the host community.

Choice of gasifier and gas clean-up technology offers an important option to be evaluated. The Future Energy/Battelle gasification/gas cleanup holds the potential of lowering capital costs but gives up some 
conversion efficiency. The marginal loss in fuel conversion seems likely to be more than covered by the reduced capital costs of the process.

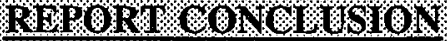

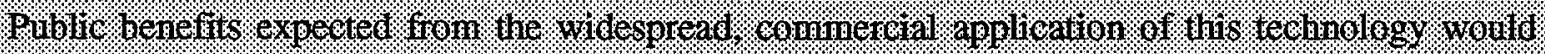

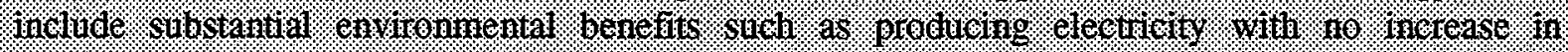

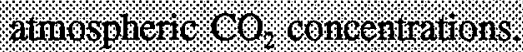

States that have quantified or monetized the external values of the pollutants that result from the conversion of various fuels into electricity have used those externalities to adjust their resource selection process.

The same processes can be followed at the federal level to guide participation in joint ventures. At the present time, no federal assessment of the various methodologies or values attached to extemalities has been undertaken. This analysis will not suggest firm quantified values but rather outline how the externalities can be expanded to justify public intervention in technology development. One original goal of federal-private joint venture was to hasten commercial deployment of technologies that could play an important role in energy security. If the environmental benefits of a technology can be estimated, they also can be used to justify public investment. It remains to be seen how the goals of energy security and environmental mitigation can be balanced or applied jointly to projects under consideration. Given the work done at the state level and by other nations, however, the initial step-the quantification of external values associated with energy use-should be relatively straightforward. If those external values can be calculated, or a band of values determined, the first step in adding the environmental consequences into the justification for public intervention is to estimate the avoided pollution that would result from this technology. The pollution avoided will have to be calculated for specific situations, a calculation not readily available for this report. However, an important initial analysis by the Environmental Protection Agency (EPA) looked at exactly that question. ${ }^{3}$

Table S-5. Valuing $\mathrm{CO}_{2}$ Reductions

\begin{tabular}{lc}
\hline Estimated Electric Production & $13,140 \mathrm{MWh}$ \\
Avoided $\mathrm{CO}_{2}$ (thousands of metric tons) & $12,353^{1}$ \\
Yearly Value: Low (at $\$ .001 / \mathrm{hb})$ & $\$ 27.2 \mathrm{M}^{2}$ \\
Yearly Value: High (at $\$ .013 / \mathrm{lb}$ ) & $\$ 353.3 \mathrm{M}^{3}$ \\
Internal Rate of Return (low value) & $136 \%$ \\
\hline 1 & Calculated using national total from EPA study, prorated for production from \\
& $2000 \mathrm{MW}$ of BIG/GT production. \\
2 & New York Public Service Company (PSC) external value for $\mathrm{CO}_{2} @ \$ .001 \mathrm{nb}$. \\
${ }^{3}$ & California Public Utility Company (PUC) external value for $\mathrm{CO}_{2} @ \$ .013 \mathrm{hb}$.
\end{tabular}


The EPA analysis can initially quantify avoided air pollutant values. Next, one estimates the saturation of the technology once successful commercialization is completed. The number of deployed megawatts are calculated and a total avoided pollution is derived. If the initial public investment in is roughly $\$ 1000 / \mathrm{kW}$, and the joint venture leads to installed capacity 100 times greater than the demonstration of $20 \mathrm{MW}$, the yearly payback is between 1 and 18.

Ultimately, this evaluation of the retum on public funds must be weighted by some estimate of the probability of the success of the joint venture, since it is unrealistic to expect all joint ventures to succeed. That public gain, while subject to some margin of error, supports the investment of public funds.

An additional method of assessment is to attempt to calculate the environmental benefits by per-kW of installed capacity and per-kWh of electricity generated. This would involve many of the calculations discussed above as well as the "cost" of public funds used to produce electricity with no $\mathrm{CO}_{2}$ emissions. This cost calculation again uses the saturation estimate of 100-to-1. An outline of this process follows.

\section{Options for $\mathrm{CO}_{2}$ Stabilization}

Energy and environmental policies can be integrated to stabilize $\mathrm{CO}_{2}$ emissions by using three approaches:

- Increase the efficiency with which we use energy.

- Increase natural gas use.

- Develop new technologies that break the link between energy production and environmental damage and deploy them in the market.

\section{$\mathrm{CO}_{2}$ Stabilization as an Advanced Technology Goal}

The stabilization of $\mathrm{CO}_{2}$ can be aggressively pursued even without large carbon taxes. $\mathrm{CO}_{2}$ reductions can be an important public benefit and identified as such in new technologies. Part of the risk of developing technologies to capture the public benefit can be underwritten in joint ventures. The following conditions apply:

- The technology must have demonstrated $\mathrm{CO}_{2}$ stabilization benefits.

- Market potential beyond initial deployment must be on the order of 100 to 1 . For example, the demonstration of $20 \mathrm{MWs}$ of a technology must be likely to lead to the market development of 2000 MWs.

- Initial private participation must cover $50 \%$ of the project cost.

- Public participation must write-down the unique costs of initial commercial deployment of advanced technologies, or provide $50 \%$ of the project cost, whichever is less.

\section{Project Benefits}

Project benefits include the following:

- Biomass projects provide substantial local benefits, particularly to rural communities.

- As agricultural crop support programs are phased out, energy crops can revitalize local communities. 
- The very high conversion efficiencies of the advanced technologies are critical to making this agricultural conversion happen without ongoing federal subsidies or higher retail electric prices.

- These technologies, developed and perfected domestically, will enjoy substantial world-wide application as other nations join efforts to stabilize $\mathrm{CO}_{2}$ and other greenhouse gas emissions.

\section{Project Participation}

Assume the market deployment potential for technologies is 100 to 1 , and public funding of $\$ 1000 / \mathrm{kW}$ is committed for public cost sharing of the initial pre-commercial project development. The public cost of producing electricity with no adverse $\mathrm{CO}_{2}$ or other global warming consequences is $\$ 0.15 / \mathrm{MWh}$ (assuming 100-to-1 deployment, 10\% discount rate, a 75\% capacity factor, and a 20-year life).

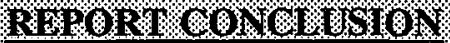

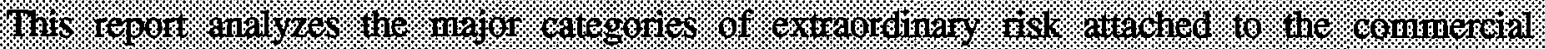

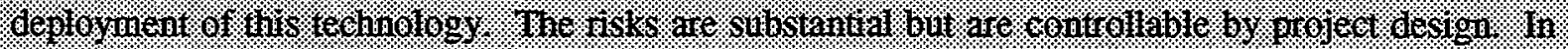

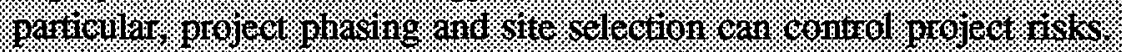

\section{Risks}

The types of risks being discussed fall into five categories:

- Developmental-Costs of construction are uncertain in a first-time venture. Sub-optimal design or choice of equipment may be dictated by the developmental path.

- Operational-Equipment may operate, but not to specifications or expectations. Operational problems would manifest themselves as increases in operation and maintenance expenditures and would depend upon factors such as gas cleanliness.

- Financial-Costs of capital may be higher because of general uncertainty.

- Coordination-This is not really a risk, but a cost caused by altering the time schedule to satisfy a federal or public timetable.

- Fuel Supply-For programs that rely on dedicated fuel supply systems, the risk of developing and testing those systems will have to be assessed. For programs that rely on waste biomass, risk would come from conditions placed on the harvest or waste source to assure sustainability.

The developmental risks carry the most severe financial impact. For the BIG/GT, turnkey capital costs range from $\$ 900 / \mathrm{kW}$ to $\$ 1500 / \mathrm{kW}$ depending upon the estimates for the gasifier, gas cleanup, and turbine costs. Aero-derivative turbines under consideration are an extremely well-known commodity and are available on a turnkey basis from a variety of original equipment manufacturers. The one uncertainty with the turbine involves modifications to accommodate the particular Btu content of gas produced from the gasifier. To the extent that a gasifier produces a medium Btu gas, it is expected that even this uncertainty will be substantially reduced. With respect to the gasifier and the gas cleanup process, it seems prudent to anticipate that the first-time cost could be as much as $50 \%$ to $100 \%$ above the expected turnkey cost 
of the equipment. The total project cost will be greatly reduced if an initial project can be developed at a site with fuel handling and processing equipment in place.

Operational risks are largely controllable by the structure of the development process. If the first-time venture were at a "green field" site involving the integration of a gasifier and a turbine, with no independent testing of the gasifier, the risks would be substantial. They could range from establishing fuel-handling processes to anticipating the gas cleanliness and the suitability of the gas for use of the turbine. The structure of the initial joint venture can greatly reduce this risk. If the technology can be situated where fuel handling experience and equipment is available, uncertainties would be greatly reduced. Additionally, if the project is structured to independently establish gasification process and/or provide a readily utilizable back-up fuel, the operational risks would be greatly reduced. Finally, operational risks can be minimized if a supplemental or back-up fuel is available. Revenues can be maintained even if severe operating problems are experienced. Again, in the worst case, the inability to use the gas produced could lead to no production of electricity and no return on investment. This risk would greatly increase the necessity for public financing. If, on the other hand, the first venture can be structured to limit exposure of the investment in the turbine to conditions where it can be expected to produce electricity, the initial risk and the requirement for public funds are greatly reduced.

The ability of capital markets to recognize the public benefits of a project and support that project should not be overestimated. Without low-cost, tax-exempt economic development or other financing, the commercial cost of capital for a project using an untested technology would be substantially greater than normal. In the assessment of the turnkey economics, no explicit recognition of that factor was attempted. The only way to control this financial risk is to have a certificate of public necessity (if it is developed by a private utility) or a power contract (if it is developed by an independent power producer). That contract, in conjunction with the availability of a back-up fuel, will produce a fail-safe stream of operating revenue and capital cost recovery that can substantially protect the project's bond and equity holders. This provides an upper limit on the risk to non-federal participants and should increase their ability to raise money.

Coordination risk is a potential cost that would arise from a different timetable to satisfy the public interest in developing the technology as quickly as possible. For example, coordination risk would arise if the utility or developer saw no need for additional capacity until 1999, but the public interest sought to move the technology by 1997. Coordination cost would come from moving the construction and utilization of capacity forward a number of years.

Fuel supply risks are especially severe for projects using a dedicated fuel supply system. It is anticipated that the initial project will use wood chips from forest residues or waste wood, rather than a dedicated fuel supply system. However, an important and immediate follow-on should be to develop markets for switchgrass, where the need for a dedicated fuel supply system is substantial.

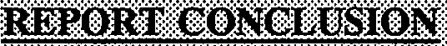

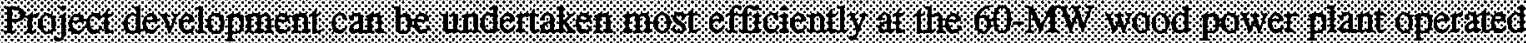

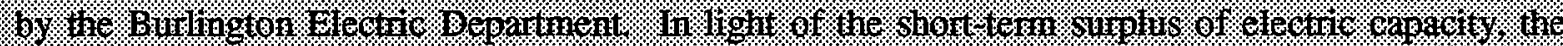

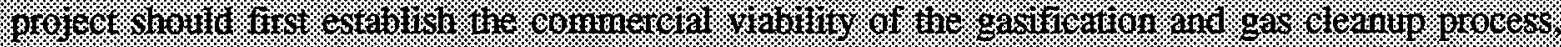

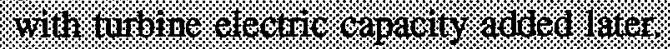


In March 1990, the Burlington Electric Department (BED), a municipal electric serving the city of Burlington, completed an engineering assessment of additional options for increasing the generating capacity of the McNeil Generating Station, a $60-\mathrm{MW}$ wood-fired central station modified to fire natural gas as a supplement to the primary wood fuel. Among the 15 alternatives considered for increasing station capacity, one consistently given favorable reviews called for the addition of a natural gas-fired aeroderivative turbine. The study proposed the use of an LM 2500 turbine and either a heat recovery steam generator or using the waste steam to dry the wood chips.

BED developed its long-run plan for providing least-cost service in 1992, identifying five major options for meeting the long-range need for power (relevant portions of the plan are attached as Appendix 5). Initially, the long-run integrated resource plan discusses adding a 15.25-MW gas turbine at McNeil. As a footnote, the plan notes that "The Public Service Department has announced it will study a wood-fired gas turbine unit to be located in Bennington County. We may be able to join with the PSD where it may be feasible to replace the McNeil GT expansion with a similar unit." In the spring of 1993, the Board of Electric Commissioners which oversees BED passed a resolution to consider locating a biomass gasifier and integrated combined cycle turbine at McNeil (Appendix 5). The commissioners asked management to discuss a joint venture to consider the use of a gasifier/gas turbine at the McNeil site, including ways to further project development while still protecting consumers "from development risks."

Burlington Electric's interest in expanding capacity at the McNeil Station with the addition of an aeroderivative turbine engine makes it a uniquely advantaged participant in a joint venture. Although the decline in electric demand has likely pushed back the need for the next increment of capacity, the ability to separate the development effort into a gasification and capacity stage argues for close consideration of the role Burlington could play in a joint venture. Burlington has already done preliminary engineering work that shows the addition of an aero-derivative turbine is feasible and desirable. Schematics attached as Appendix 5 show the various sites for the addition of the turbine. Because the existing 60-MW plant is wood-burming, much of the initial cost of permitting already exists and could be considered part of BED's contribution to the joint venture. BED also has experienced personnel for the project.

Burlington Electric has used between 400,000 and 160,000 tons of wood chips per year since 1984. The Chief Forester at BED conducted an initial analysis of the "impacts on wood procurement issues of increasing current wood fuel demand at McNeil Station by 150,000 tons per year." (Full report is attached as Appendix 5.) The assessment of the impact of adding a 20-MW aero-derivative turbine is as follows:

There appears to be no insurmountable obstacle to procuring adequate wood to fuel a 150,000 ton per year additional demand at McNeil. There will be additional costs associated with increased wood demand, handling and transportation that could negatively affect McNeil Station's level of dispatch by the New England Power Pool.

Negotiations are underway between BED and private developers to determine the level of interest and concerns. The following conclusions can be reached:

- The McNeil site has been evaluated for the use of a gas turbine, which BED sees as a desirable avenue for expanding capacity.

- The addition of up to $20 \mathrm{MW}$ of aero-derivative capacity could be done within permitting regulations now governing the purchase and delivery of wood to the site. Air and water quality permits must be obtained.

- The separation of the proposed project into a gasification stage could be followed by the addition of capacity, and may be desirable in light of the overall surplus of short-term capacity in the northeast. 
- In addition to the permitting and delivery aspects already in place, the availability of a wood yard and wood-handling equipment, the experience of plant operators with that material, and the availability of a back-up fuel such as pipeline gas argue for giving special consideration to a joint venture at Burlington over a green-field site. Although no rigorous quantifications of the cost advantage have been conducted, the equipment, handling experience, and permitting already in place should reduce project development costs by roughly $\$ 5$ million.

- Finally, the development of the project at McNeil has the advantage of providing a commercial use for processed gas produced during the scale-up and development stages. If this were to last 1 to 2 years, the gas utilization could provide an additional substantial advantage in terms of reducing the ultimate cost of the initial phase.

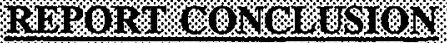

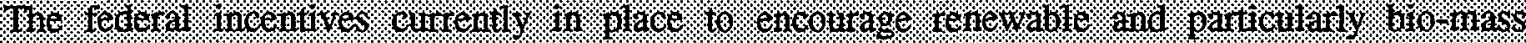

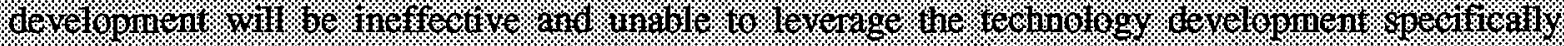

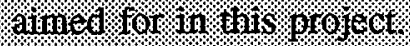

Federal incentives to encourage biomass energy production are currently provided in the tax code, the Clean Air Act Amendments (CAAA) of 1990, and the Energy Policy Act (EPACT) of 1992.

The Internal Revenue Code provides for a tax credit of $\$ 5.5 / \mathrm{bbl}$ oil equivalent for gasified fuels. This credit is extended for projects that come under contract by 1996. The credit is available until 2008 but is subject to the alternative minimum tax calculation.

The CAAA of 1990 provide for bonus allowances for renewable electric projects that come on-line between 1995 and 2000. Moreover, the CAAA should provide a permanent advantage to biomass projects because the low sulfur emissions will mean an allowance will not have to be purchased to offset $\mathrm{SO}_{\mathrm{x}}$ emissions.

The EPACT provides a very ambitious $\$ 15 / \mathrm{MWh}$ tax credit for private developers (or $\$ 15 / \mathrm{MWh}$ payment to public entities) for renewable biomass projects. The tax credit is limited to "closed loop" biomass feedstocks.

All of these incentives taken together will be unable to move or leverage the type of technological evolution envisioned in this project. First, many of the incentives such as the CAAA allowance offset, are of a very small consequence. The more significant incentives, such as the $\$ 15 / \mathrm{MWh}$ tax credit (or direct payment for public entities) are of either extremely limited use or are not funded.

In addition, the incentives in the CAAA and EPACT are aimed primarily at increasing the use of biomass feedstocks rather than developing new technologies. The technologies now available to convert biomass to electricity are limited to the steam or Rankine cycle. Natural gas, oil, and even coal may be used in the new generation of much higher efficiency aero-derivative and industrial turbine engines. This limitation translates into an enormous disadvantage or penalty for biomass fuels.

The commonly accepted view of inter-fuel competition is that the fuels compete on a $\$ \mathrm{MMBtu}$ basis. This view ignores the conversion efficiency-the efficiency at which those fuels can be converted to electricity. The actual basis of comparison for fuel converted to electricity is: 


$$
\begin{aligned}
& \begin{array}{l}
\text { Normalized Fuel Costl versus Normalized Fuel Costl } \\
\text { IProcess A }
\end{array} \\
& \begin{aligned}
\text { where Normalized Fuel Cost } & =\text { Fuel Cost } * \text { Net Fuel Usage } \\
& =(\$ F u e l / M M B t u \text { Fuel })(M M B t u \text { Fuel/kWh) } \\
& =\$ F u e l / k W h
\end{aligned}
\end{aligned}
$$

IProcess B

As long as the conversion of efficiencies is the same, the actual point of competition is the $\$ / \mathrm{MMBtu}$ cost. However, biomass is currently unable to avail itself of tahe new generation engines that use more efficient conversion technologies.

In typical-size biomass applications, the conversion efficiency is limited to $20 \%$. Simple cycle aeroderivative turbines get $30 \%$ to $35 \%$ efficiencies. In advanced applications, efficiencies in the mid-40s are claimed.

The delivered price of natural gas to electric utilities in 1990 was $\$ 2.38 / \mathrm{MMBtu}$ [EIA]. ${ }^{2}$ Using that figure and the conversion efficiencies above $20 \%$ for biomass and above $35 \%$ for natural gas means biomass would have to sell for less than $\$ 1.36 / \mathrm{MMBtu}$ to be competitive.

Eliminating the conversion efficiency penalty would be the most important step to take to increase the competitive position of biomass fuels. None of the present incentives even attempt to do that. DOE participation in a joint venture would aim to achieve precisely that goal.

\section{RUDORT ROAUVUSHOK}

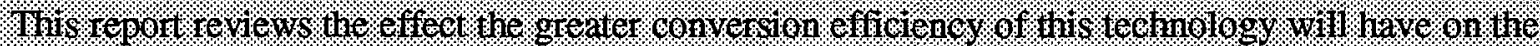

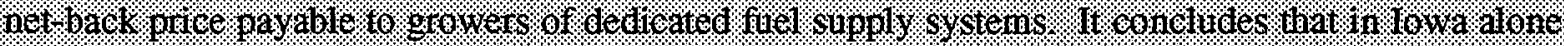

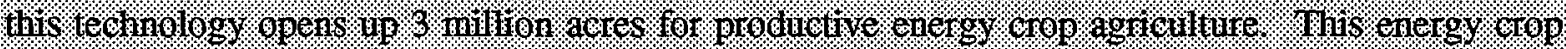

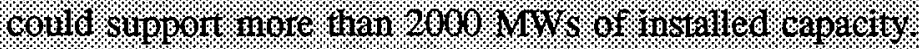

Two programs operate in Iowa to stabilize farm income and contribute to soil conservation: the set-aside and crop reduction programs. The crop reduction program, a 10-year contract between farmers and the federal government, has moved about 2 million acres from production. The set-aside program, using federal price supports, removes another 1 million acres from production. Total agricultural production in Iowa is about 30 million acres, so about $10 \%$ is under federal crop or land reduction programs that are scheduled to end in the next 4 years.

Switchgrass as a fuel crop will yield approximately $16 \mathrm{MMBtu}$ per ton, bone dry. Crop yields are about 3-5 bone dry tons per acre. According to an economic analysis presented in more detail as Appendix 6 to this report, a low estimate of the economic threshold price for switchgrass is approximately $\$ 35 /$ ton dry delivered. At that price, a portion of the 3 million acres in the crop production and set-aside programs could be converted and permanently devoted to switchgrass production. The 3 million acres would support approximately $3300 \mathrm{MW}$ of capacity. A 20-MW plant requires approximately 73,500 tons annually, or the yield from approximately 18,000 acres.

There is undoubtedly a more graduated supply curve for production in Iowa, reflecting the fact that all 3 million acres in crop reduction and set-aside programs will not produce uniform yields of switchgrass for a uniform price per ton. If the price that could be economically supported in the production of 
electricity would fall substantially below $\$ 35 /$ ton, then the acreage committed, the crop yield sustained, and the megawatts supported would be significantly lower. Simultaneously, if the $\$ 35 /$ ton figure could be exceeded, a substantial portion of the 3 million acres could be productively switched to the long-term sustained production of a fuel crop. Table S- 6 estimates how the energy conversion affects the price that can be supported to grow switchgrass.

This increase in efficiency shows a striking differential in the potential return. At 20\%, the net-back price to the switchgrass growers is significantly below what is estimated as necessary to provide for the economic long-term transition to growing switchgrass as a cash crop. By increasing to $30 \%$ (an overall efficiency well within the reach of gasification and aero-derivative turbine technology), the net-back price to growers increases to $\$ 42 /$ ton, a price above the threshold cost estimated by the Iowa Agricultural Collaborative. One could conservatively predict that were this technology available, it would support significant applications in Iowa. If one makes the bold assumption that overall efficiency will be $40 \%$,

Table S-6. Net Back Pricing and Conversion Efficiency

1. Rev/ton $=\left[\mathrm{R}_{\mathrm{e}} *\left(\mathrm{Crop} \div \mathrm{Tech}_{\mathrm{fR}}\right)\right]$

where

$R_{e}=$ Revenue for fuel $=$ Avoided Cost - Capital Recovery Factor.

Crop $=\mathrm{MMBtu} / \mathrm{dry}$ ton

$\mathrm{Tech}_{\mathrm{HR}}=\mathrm{Btu} / \mathrm{kWh}$ for Conversion Technology

2. Conversion Efficiency @ 20\%

$$
\begin{aligned}
\text { Rev/ton } & =[.03 / \mathrm{kWh}\{16 \mathrm{MMBtu} / \mathrm{ton} \div 17060 / \mathrm{kWh}] \\
& =\$ 28.136 / \text { ton } \\
& =\$ 1.756 / \mathrm{MMBtu}
\end{aligned}
$$

3. Conversion Efficiency @ 30\%

Rev/ton $2[\$ .03 / \mathrm{kWh}\{16 \mathrm{MMBtu} /$ ton $\div 11333 / \mathrm{kWh}\}]$

$=\$ 42.35 /$ ton

$=\$ 2.647 / \mathrm{MMBtu}$

4. Conversion Efficiency @ 40\%

Rev/ton $2[\$ .03 / \mathrm{kWh}\{16 \mathrm{MMBtu} /$ ton $\div 8530 / \mathrm{kWh}\}]$

$$
\begin{aligned}
& =\$ 56.27 / \text { ton } \\
& =\$ 3.517 / \mathrm{MMBtu}
\end{aligned}
$$


the return per ton is well above the threshold level required for conversion. At this level, the conversion of land currently held in the crop reduction and set-aside programs could significantly revert to the provision of crops for energy purposes-specifically, for the generation of electricity.

If only two-thirds of the available land were converted to switchgrass and the production of electricity using this technology, the process would lead to the introduction of slightly more than $2000 \mathrm{MW}$ of capacity in Iowa. It is arguable that the leveraging of the technology is justified in terms of the impact in Iowa alone. It is unrealistic to assume the technology would be applied only in Iowa, and this report will not support that argument. It does support the assumption that the 100-to-1 leveraging ratio applies to this technology and that it is a realizable and even conservative assumption.

In addition to reviewing the technical literature on the technology, the statutory provisions, and the biomass research and development (R\&D) program already underway, this project supported discussions of possible project development with private developers and local and state authorities. It recognizes that feasibility depends upon both the analysis and the real-world potential.

\section{RTROATIOONOLSSION}

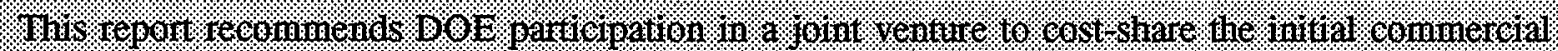

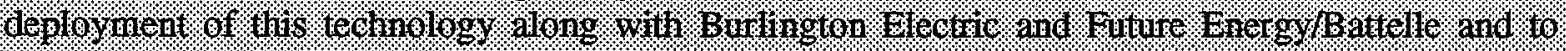

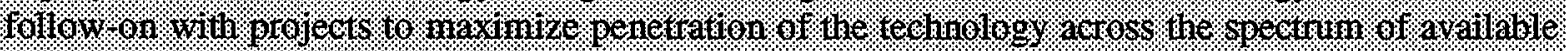
fite 15.

Right now, non-federal participants stand ready to bring substantial resources to an initial project. The State of Vermont has reviewed the potential of multiple applications. The City of Burlington and its municipal electric company, BED, have reviewed the substantial resources and technical expertise they can offer. Future Energy of Atlanta, in conjunction with Battelle Laboratories of Columbus, Ohio, has expressed a willingness to invest in the initial project.

DOE would buy-down the expected increment to cost. The project would operate for 1 to 2 years to demonstrate the technology, validate the gas cleanup, and test multiple fuels. Participation initially would consist of a small core group. The project would actively seek other participants.

In the current regulated marketplace for electricity, all new measures must compete against an established avoided cost. Subtracting the capital cost recovery leaves a revenue to cover fuel cost. If the conversion is inefficient, large amounts of fuel must be used to generate electricity and earn revenue. Inefficiency leads to low net-back prices to support the fuel. By increasing the efficiency of conversion, it is possible to pay more for the fuel or support wider utilization. The gasification of biomass and integration with aero-derivative turbines represents a gigantic increase in conversion efficiency. This report finds that, in Iowa, what is at present not economic (growing switchgrass to produce electricity using current combustion technology) becomes economic if conversion efficiency gains can be delivered. Up to 3 million acres currently not cultivated could be converted to produce switchgrass or other energy crops and support in excess of $2000 \mathrm{MWs}$ of capacity. If this is sustainable, the gain in $\mathrm{CO}_{2}$ stabilization would be enormous. 
The following project description is being circulated among interested parties to determine if it could serve as a basis for moving ahead. It represents broad agreement, but will require negotiation to become a format by a recognized memorandum of understanding.

Initial Objective: The initial objective is to develop a fully operable multi-fuel 200 ton/day biomass gasifier based on indirect gasification technology developed by Battelle Columbus Laboratories (BCL) and commercialized by Future Energy (FE) to supplement the electrical output of the BED McNeil Station.

Technical Description: This is a two-phase project. In the first phase, the existing BCL technology will be scaled up from 12 to 200 tpd with the gas being used in the McNeil boiler. The gas quality and the response of the gasifier to feedstock and quality variations will be determined to assess the modifications necessary to incorporate a gas turbine in a combined cycle configuration at McNeil. The second phase involves the incorporation of a suitable 15-to-20-MW gas turbine (e.g., a GE LM 1600) and the use of turbine waste heat in the McNeil boiler. While the first option will not increase the station's output, the second will provide a significant (30\% to $40 \%$ ) capacity increase for only a small increase in fuel consumption. During the second phase, the potential for a slip-stream demonstration of other advanced electrical generation systems such as fuel cells will be evaluated.

Time Phasing of the Project:

Concept Paper Due June 14 (NWEA Washington presentation)

Participants: All

Funding Discussions June to July

Participants: DOE/BED/FE

Consortium Creation Selection of A\&E, management structure, participation of interested parties

(See attached organizational chart)

Detail Design $\quad$ October 1993; Complete spring 1994

Participants: BED/FE(A\&E + BCL)

Permitting BED/State/EPA

Construction Summer 1994 (depends on permits)

Participants: BED/FE/subcontractors

Startup Winter 1994 to Spring 1995, Offline to flare

Summer 1995, Connection to boiler

Operation Summer 1995 to Summer 1996, Phase II Gas Turbine addition

Predesign/Planning for

$\begin{array}{ll}\text { IGCC } & \text { Winter 1995 } \\ \text { Design } & \text { Summer 1996 } \\ \text { Installation } & \text { Fall 1997 } \\ \text { Operation/Testing } & 1998\end{array}$

The preliminary phase I capital and investment cost is $\$ 13 \mathrm{M}$. The operation and testing phase might be structured to provide operators and maintenance. Purchase of the wood fuel and supply gas will 
be negotiated to obtain the necessary performance for gasifier validation during the test run. The use of fuels such as switchgrass and bagasse will be allowed as permitting and procurement issues are resolved. BCL will provide analytical services. Estimated annual costs are: four persons at McNeil- $\$ 200,000$; wood fuel 200 tons per day at $\$ 17 /$ tons for 200 days $-\$ 68,000$; and analytical R\&D services- $\$ 500,000$, for an annual running cost of $\$ 1.4 \mathrm{M}$. The total Phase I cost is $\$ 14.9 \mathrm{M}$; with a project contingency of $10 \%$, the final cost is $\$ 16.5 \mathrm{M}$.

The establishment of follow-on projects in Iowa is estimated at $\$ 25 \mathrm{M}$ for crop development and project construction. Negotiation of the appropriate federal buy-down for subsequent projects awaits more detailed engineering analysis. In Phase II, the additional cost of the turbine and modifications and installation is estimated at $\$ 15 \mathrm{M}$.

Management Group: BED and the joint owners of McNeil (GMP, CVPS, and VPSA), FE, BCL, and DOE. BED will be general project manager.

\section{Ownership: FE/BED}

Funding: FE, with federal buy-down support; BED with in-kind contributions. Iowa and other parties will obtain permits and funding for additional fuels. 


\section{Review of Technology Status: Brazilian/World Bank Project}

In December 1991, the World Bank GEF approved the two-phase development of BIG/GT technology. The financed project marks the highest stage of development of this technology. As such, it must be reviewed to understand how the project is intended to proceed and to structure a domestic project to extend the World Bank effort.

The initial GEF project will be developed in Brazil. The development team is composed of Brazilian companies, ranging from electric utilities to forestry and research and development companies. The core Brazilian group is joined by SHELL Brazil and SHELL International Petroleum Company.

So far, the development process of the World Bank project is similar to the pre-feasibility phase for a domestic process. A major goal of the project was to organize core developers willing to sign a memorandum of understanding. This memorandum became the basis for the World Bank's commitment of funds for the remaining development.

A critical difference between Brazil and a domestic project is that the core development group in Brazil is concerned with a single site and does not appear to include representation from other Brazilian sites or World Bank country members. The domestic development seeks cooperative representation.

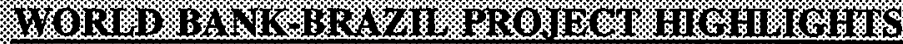

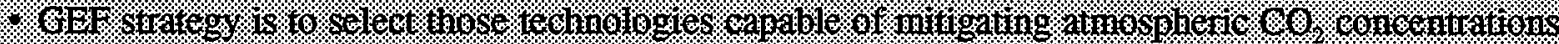

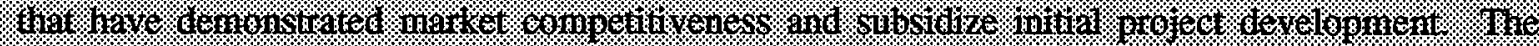

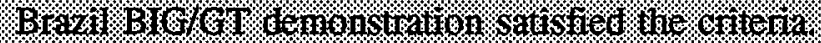

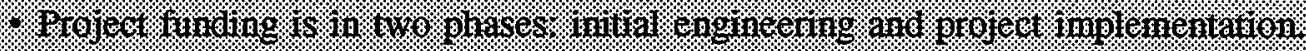

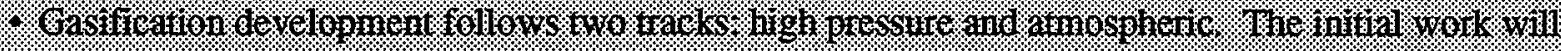
OG

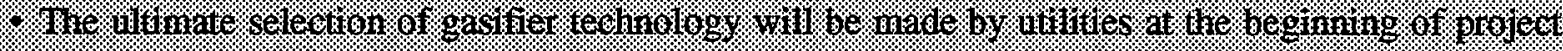

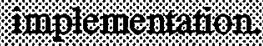

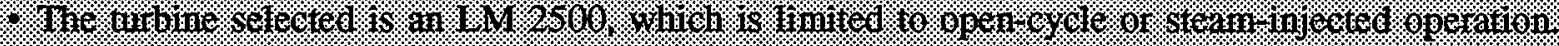

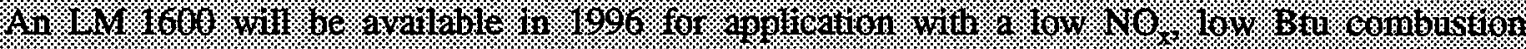

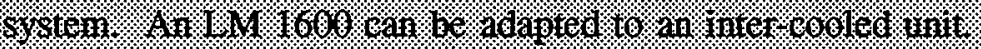

\section{A. Pre-Development Goals}

The Brazilian/World Bank pre-development phase focused primarily on obtaining the memorandum of understanding. The process focused on specific tasks, such as exploring the basic technology options, identifying a short list of equipment manufacturers, and drafting a work-outline for the first development. The pre-feasibility effort sought to provide the GEF with a basis for determining the commercial viability of the technology in order to assure the World Bank that development funds-totaling $\$ 30$ million over two stages-would leverage substantial commercial development. In this critical task, the project succeeded. 
The core group recognized that the optimum potential of BIG/GT technology lies in evolutions of the turbine technology not quite ready for commercial application. The participants chose to use existing commercial technology, recognizing that substantial demonstration of market potential will result from using the less-than-ideal technology available today. They also adopted an intent ". . . to choose a cycle configuration, main system components and equipment manufacturers with a view to making the maximum contribution towards the long-term development goals of BIG/GT technology."4

This statement of project philosophy is enormously important. It signals a willingness by the private participants to look beyond the narrow commercial interest that could shape equipment selection and development strategy. It is, in a sense, the factor that balances or justifies the public support given to the technology.

\section{B. Project Development}

In drawing lessons from the Brazilian experience, it is important tolook at the technology selections made. But first, one must assess the World Bank/GEF development process and compare it with the statutory authority under which a domestic project will be assessed. According to a recent World Bank report:

The GEF has broken new ground by making financing available for pilot projects to identify the scope for widespread replication and cost reduction of technologies and practices that will lower net greenhouse gas emissions. Its priorities include ... developing renewable sources such as biomass, solar energy, and micro hydropower. . 5

The Brazilian Biomass Power Generation Report (1992, p. 1) ${ }^{6}$ stated:

The GEF arises to promote investment in specified areas of environmental maintenance, including measures to reduce the rate of accumulation of atmospheric carbon dioxide ... it is believed that a major role for the GEF exists in bringing forward selected renewable energy technologies which appear relatively close to commercialization. BIG/GT technology is perhaps the best example of an energy technology with the potential to make a substantial impact on the carbon cycle which could become cost competitive with conventional fossil-based electricity as it moves down the technology learning curve.

The GEF sees its function as bringing forward technologies with a specific environmental benefit, namely the reduction of atmospheric $\mathrm{CO}_{2}$. Assessment of the eventual market competitiveness also is important. The role of GEF funding is presumably to reduce the high initial cost. The funding is a supplement to private funds; public funds are not intended to undertake the investment so much as to leverage private investment.

The funds dedicated by the GEF were divided into two parts: $\$ 7$ million for engineering work and $\$ 23$ million for an implementation grant. The engineering grant was divided into three parts to underwrite additional work by a chosen "short list" of equipment manufacturers who were likely to be participants in the program implementation.

The Brazilian project set aside $\$ 7$ million to develop technology capable of being used for project implementation. The project was designed to allow a substantial modification or adaptation of wellestablished gasifier and turbine generation technology to prepare it for use in the implementation phase. 
The project set out two competing development teams led by gasifier manufacturers with different technologies. One team used a high-pressure or pressurized gasifier technology, the other a low-pressure gasifier. The gasifier producers are expected to be responsible for the following:

- Performance of the gasifier, clean-up technologies

- Integration of gas turbine and steam bottoming cycle

- Overall system control

- Provision of process guarantees.

The selection between the two teams will be accomplished by a formal Request for Proposal (RFP) to equipment developers. It is not clear why the gasifier producer should be responsible for such functions as the integration of turbine and steam-bottoming cycle. While many aspects of the Brazilian/World Bank project are useful, this feature may not be. For a domestic project, the critical project leader will be a utility or independent power producer. The role for equipment manufacturers can vary from supplying equipment at commercial terms to a more active equity position.

\section{Turbine Selection}

The turbine selected for the Brazilian implementation phase is the GE LM 2500. The World Bank team identified the LM 1600 as most suited for project use, but found subsequent problems in getting a turbine modified to burn low-Btu gas. The development philosophy-to choose and configure a project to make a maximum contribution to long-term technology development-favored selection of the LM 1600.

According to the report:

The TF-39 engine provided the basis for the LM 2500 gas turbine, a 21-MW machine with $35.5 \%$ open efficiency. With a steam injection level of $40,000 \mathrm{lb} / \mathrm{hr}$, the $\mathrm{LM} 2500$ is uprated to $26.5 \mathrm{MW}$ at $40 \%$ thermal efficiency . . . GE has introduced another aeroderivative, the LM 1600 . . . In open cycle, without steam injection, the LM 1600 is rated at $13.4 \mathrm{MW}$ with an efficiency of $35.5 \%$. In the steam injected configuration . . the LM 1600 is capable of 17 MW output at $40 \%$ thermal efficiency ... The next stage in the development of the aero-derivative engine . . . is the addition of inter-cooling. One prerequisite for the incorporation of inter-cooling is a multi-spool design. The compressor must have separate low and high pressure sections, each driven independently by its own turbine. This excludes all current industrial engines and also single spool aero-derivative, such as the Rolls Royce Avon and the GE LM 2500 from this development option." 7

The LM 1600 is smaller than the LM 2500, has roughly identical operational efficiencies, and can be modified to develop the technology to the next level: inter-cooling. Initially, GE agreed the LM 1600 could be adapted and provided cost estimates.

The engineering modification envisioned for the turbine manufacturer, GE, in the first phase of the project was the adaptation of the combustion system to accommodate the relatively low-Btu gas produced by gasifiers. GE is already engaged in modification of the LM 1600 to reduce $\mathrm{NO}_{\mathrm{x}}$ emissions; this adaptation will also accommodate the use of low-Btu gas. According to the report:

GE is reluctant to instigate a separate low-Btu fuel programme since this capability will follow almost as a by-product of the low- $\mathrm{NO}_{\mathrm{x}}$ programme.

In the Brazilian project, GE will undertake modifications to the LM 2500 that it is confident it can make. 
Despite intentions to select technology with maximum potential for demonstrating its technical potential, the Brazilian project will initially use an LM 2500 single-spool turbine. Modifications of the LM 1600 for reduced $\mathrm{NO}_{\mathrm{x}}$ emissions are to be completed by 1996, making utilization of this turbine suitable for an initial domestic project. A follow-on using the LM 1600 would make it possible to include inter-cooling, a phase expected to further increase thermal efficiency and provide a competitive edge.

\section{Gasifier Technology}

The Brazilian project is quite clear that the long-term, optimum technology design for utilizing biomass energy is advanced turbine designs employing inter-cooled steam injected or inter-cooled regenerative technology. The report states:

The long-term goal of BIG/GT technology development is the close coupling of a pressurized biomass gasifier with an advanced gas turbine cycle ...?

The technical challenges of using a pressurized gasifier can be overcome within time and budget limits. The most serious shortcoming of pressurized gasifiers is that few companies have experience operating units of the size required and that can handle biomass. Additionally, clean-up technologies remain to be verified.

To make maximum progress toward technology development while maintaining a satisfactory level of technological prudence, "the project chose deliberately to initially develop two gasifier technologies: atmospheric and pressurized." ${ }^{10}$ Ideally, three teams would independently develop gasifier technology - one atmospheric and two pressurized—but project funds would not support this. Instead, two pressurized gasifier manufacturers competed to head up the effort to develop a pressurized gasifier: BioFlow (Ahlstrom/Sydkraft) and UHDE.

Project leaders chose not to put all their eggs in one basket. While pressurized gasifier technology on paper is closest to optimal, the added uncertainties of scale-up and clean-up problems led GEF to encourage the development of an atmospheric gasifier team. The selection of gasifier technology and the resolution of clean-up problems also remain issues for a domestic project. It is important to review the GEF teams' assessment of risks to each technology and how they sought to remove the risks through the initial phase of engineering work. It is critically important to examine the trade-off between the higher capital costs of pressurized hot gas clean-up technology and the efficiency gains it brings. There is a diminishing return to bottom-line profitability from increasing the overall system operating efficiency; this will be examined much more closely in assessing options for a domestic project.

\section{Atmospheric Gasifier}

The atmospheric gasifier proposed by TPS Studsvik is a circulating, fluidized bed design. The FB gasifier fuel operation is relatively tolerant of size variation in the feedstock material. One perceived limitation of an atmospheric gasifier, compared to a pressurized unit, is its greater size requirement and cost. According to Studsvik, this becomes a concern only at sizes above $80-\mathrm{MW}_{\mathrm{e}}$ scale. Both Studsvik and the project team believe the atmospheric gasifier championed is "technically well advanced towards integration with a gas turbine." ${ }^{11}$ Gas cleanup is accomplished with cyclones and conventional baghouse filters. Efficiency penalties of the atmospheric gasifier are slight, according to TPS Studsvik. An analysis of a combined-cycle operation showed a total efficiency of 44\%, using a GE LM 1600 turbine. The Studsvik process has been demonstrated for 1700 hours using wood fuels to power a 2-MW pilot plant. 
Studsvik also supplied capital cost estimates for a hypothetical plant, producing co-generated heat, using an LM 1600 turbine and a 50-MW gasifier. Development costs are estimated to be between $\$ 2500$ and $\$ 3000 / \mathrm{kW}_{e}$, dropping to turnkey costs of $\$ 1500 / \mathrm{kW}_{e}$ after three to five plants are constructed. ${ }^{12}$

\section{Pressurized Gasifiers}

Two manufacturers competed to head the pressurized gasifier development team. UHDE, participating with a Scandinavian utility, is developing a high-temperature winkler (HTW) technology, demonstrated at a coal gasification facility to produce methane. This process has run successfully for 6 years and is being further modified for integration with combined-cycle power plants. Of major concern is the use and performance of ceramic filters for hot-gas cleanup. UHDE has proposed to construct a 133-MW $\mathrm{MW}_{\mathrm{th}}$ gasifier for use with a gas turbine, which would support 60 to $70-\mathrm{MW}_{e}$ generators; the cost estimate was $\$ 81.45$ million. According to the Phase I Final Report, ${ }^{13}$ when preparing this initial response, UHDE had done no work to determine the applicability of the HTW process to smaller, biomass applications. UHDE submitted a proposal to the GEF team for completion in the first phase of the work, but it was judged too costly.

Sydkraft, a Swedish private energy group, has constructed a 6-MW $\mathrm{MW}_{e}$ demonstration plant to be run under a range of conditions to provide necessary data for full-scale operation. According to their Phase I Final Report:

The plant will be operated not only for the commercial production of electricity, but also for full-scale testing of different biomass fuel combinations. Sydkraft's aim is to use the Vamamo plant to evaluate new components and advanced process solutions in an ongoing process of pressurized BIG/GT technology development. (Engenharia 1992).

According to an earlier estimate, this technology could be developed for an 80-MW $\mathrm{MW}_{\text {th }}$ gasifier, to be integrated with a GE LM 2500 turbine, for a cost of $\$ 1040$ to $\$ 1190 / \mathrm{kW}_{\mathrm{e}}$. This estimate did not appear to include the cost of hot gas cleanup.

\section{E. Phase Two Goal for Gasified/Gas Clean-up Developers}

The work plan developed by the GEF project team had specific tasks for both the atmospheric and pressurized development teams. Before discussing the GEF analysis, it is important to recall its purpose. The economic analysis is expected to indicate market competitiveness and the amount of World Bank/GEF funding necessary for the first project in order to encourage private firms to participate.

To perform both functions, the analysis first specifies technical characteristics-turbine, gasifier, fuel lot and handling equipment-and develops first time and Nth plant costs. The Nth plant cost estimate corresponds to the turnkey cost, or the cost assessed to be a stable, long-run estimate that will deliver an operating plant once developmental questions are resolved.

Given these two estimates, the rest of the financial analysis involves specifying operating and financial parameters, such as fuel cost, depreciation, return on investment, and market cost of electricity. The financial model used by the GEF can use either a market rate for electricity as an input and calculate an internal rate of return, or use a target return as an input and calculate a produced cost of electricity.

The bulk of economic analysis for the GEF project was based on the use of a GE LM 1600 turbine with an integrated gasifier. Cost estimates were developed for a "first of its kind" project. Total costs of $\$ 49.5$ million were estimated. No detailed breakdown was included, but an Nth plant cost of $\$ 27$ million was provided. The Phase I Final Report states: 
A high specific investment cost is expected for the plant since it will be the 'first of a kind.' For subsequent commercial plants, with the same basic features, a steady decrease in specific investment costs is expected, as the development and manufacturing processes proceed down their respective 'leaming curves.'

The avoided cost or market rate of electricity for determining a threshold of feasibility was estimated to be $\$ 54 / \mathrm{MWh}$.

Given the initial investment costs, the model specified operating and financial parameters summarized in Table S-3. With these parameters, the analysis showed that a first-of-its-kind project using the LM 1600 turbine and a GEF grant of $\$ 23$ million would produce electricity at the threshold of competitiveness. The GEF grant would write-down the initial investment cost of the project so that private developers could earn a normal rate of return on their investment given the $\$ 54 / \mathrm{MWh}$ price for electricity.

The LM 2500, by virtue of its larger size (30 MW versus $18 \mathrm{MW}$ for the LM 1600), would require a higher initial investment. This investment, when written down by the $\$ 23$ million GEF grant, would produce electricity at $\$ 64.80 / \mathrm{MWh}$.

The investment costs and operating and financial parameters estimated for the Brazil project will be used, along with the DOE and EPRI estimates, in the U.S. feasibility assessment. 


\section{Department of Energy Biomass to Electricity Program}

Major development efforts have been under way under the Clean Coal Program to develop gasifier technology to integrate with turbines in combined cycle applications. DOE has recently instituted a Biomass to Electricity Program as part of the Solar Energy Conversion Office. EPRI's report on the potential for biomass power production indicates that $5000 \mathrm{MW}$ of capacity could be supported by biomass resources by 2010 . The DOE program is engaged in fundamental R\&D work and on-going efforts to encourage project developments. This section of the report will detail R\&D and technology development efforts under this program. ${ }^{15}$

The Biomass to Electricity Program recognizes that future expanded use of biomass fuels as a major component in electricity production is critically dependent upon linking biomass with the development of increasingly efficient conversion technologies. One favorable route for increasing the efficiency of conversion lies in integrating biomass fuels with high-efficiency gas turbines. The DOE program also recognizes the need for increased efficiencies for other reasons as well. Bain and Overend state:

In addition to the economic benefit of successful development of such systems, there are indirect benefits to the use of high-efficiency systems. In some parts of the country, such as California, the biomass power industry is biomass resource constrained; the replacement of present low-efficiency systems with high-efficiency ones can result in capacity growth without resource growth. From a long-range viewpoint, the use of higher efficiency systems results in power production with less environmental impact, because the biomass resource per unit of electricity production is minimized. Thus, high-efficiency systems are more desirable environmentally.

In many areas of the country, any new generation resource must compete against natural gas combined cycle and similar high-efficiency systems to obtain power market contracts and approvals for building. Thus, any assessment of the market potential of biomass projects must be critically aware of the potential for competition with natural gas. That topic will be considered in sections on the economic evaluation and analysis of various incentives available for biomass.

Although one key aspect of the separate Biomass to Electricity Program is its ability to develop and refine processes that are optimized for biomass fuel use, the program recognizes that valuable lessons can be leamed from prior operating experience and on-going work under the Clean Coal Program. Thus, Bain and Overend discuss the development process of the Biomass to Electricity Program:

Advanced systems typically involve production of a low- or medium-Btu gas by biomass gasification, followed by power generation and the gas turbine cycle. As such, biomass power systems are closely based on systems being developed and demonstrated for coal, for example, the Cool Water Texaco based Integrated Coal Gasification/Combined Cycle (IGC/CC) power plant at Daggett, California. Biomass advanced cycle development will draw heavily on the advances made for coal processing.

According to Bain and Overend, the major technical challenge facing the integration of coal or biomass gasification technology with gas turbines concerns the cleanup of various impurities found in the gas produced. The DOE program has had two major cleanup system analyses over the last two years. A fixed-fed Lurgi type gasifier in operation at the GE Schenectedy facility was tested with wood chips and bagasse fuels processed through a cyclone filtration system. The results are attached in Appendix 1. In addition, the program under management by the DOE Area Office at the National Renewable Energy Laboratory (NREL) began a project in Hawaii to scale-up the Institute of Gas Technology Renugas® 
gasification technology to partial commercial operating size and to apply cleanup technologies to examine their effectiveness. The Hawaii project draws on experience from the Clean Coal Program and the development of ceramic filters to clean up process gas to meet turbine classifications. This program works with a gasification process developed to recognize differences between coal and biomass fuel.

There are important differences between biomass and coal. Recognition of these differences offers potentially important technological and economic advantages for successful gasification processes. Bain and Overend report:

Biomass contains a high level of volatile matter (VM), and a low level of fixed carbon (FC). A typical woody biomass will contain $80 \%$ VM and $20 \%$ FC on a moisture and ash-free (MAF) basis. A low-rank coal such as the Zapp North Dakota Lignite will contain 55\% FC and 45\% VM on a MAF basis. Higher ranked coals will contain even higher FC levels, with a high volatile bituminous (HvB) coal containing approximately $60 \%$ FC (MAF). . . the differences in volatile matter, fixed carbon and elemental composition make biomass more reactive than coal and have led to different conditions for gasification. Typical gasification temperatures for non-catalytic fluid bed gasification of wood are $800^{\circ}$ to $1000^{\circ} \mathrm{C}$. For comparison, stated conditions for Texaco-based gasification of Illinois No. 6, HvBb coal are $1315^{\circ}$ to $1425^{\circ} \mathrm{C}$ (Matchak 1984). Because biomass gasification is feasible at substantially lower temperatures than coal gasification, there are differences in product composition. Biomass producer gas contains higher levels of tar than does coal producer gas, and care must be taken not to condense high boiling compounds. ... much of the coal hot gas cleanup effort has been concentrated on sulphur and particulate removal, with alkali volatility being a secondary concern. In a case of biomass, alkali and particulate removal are the primary concerns. Therefore, much of the coal-based effort does not apply directly to biomass. However, the use of ceramic filters and granular bed filters is being considered for application to biomass gasification systems.

The Hawaii project, in conjunction with Pacific International Center for High Technology Research (PICHTR), will use Westinghouse ceramic filter technology to test its use with the IGT Renugas ${ }^{\circledR}$ technology. Bain and Overend discuss gasification development and the development of gasifiers designed for biomass fuel stocks:

In the United States, gasifiers are being developed by the Institute of Gas Technology (IGT) (Evans, 1988), Battelle Columbus Laboratory (Feldman, 1988), the University of Missouri at Rola (Flanagan, 1988), and Manufacturing Technology Conversion International, Inc. (Scheifelbein, 1990). The IGT system is an air/oxygen fluid bed gasifier. The other systems are indirectly heated gasifiers, using either entrained flow or fluid bed reactors.

The IGT/Renugas ${ }^{\circledR}$ and the Battelle processes are described in more detail in attached Appendices. There are a number of commercial-scale gasifiers that have been developed and operated in the United States to produce low-Btu gas as a plant fuel. These projects were relatively small in size and not particularly concerned with gas cleanup. A number of gasifiers have run into operational problems; several have been shut down because of problems with obtaining fuel and/or obtaining fuel at a competitive price. The EPA has been in contact with a number of these people and has negotiated with them concerning their desire and availability for participation in larger joint ventures of the type envisioned in this paper. A summary is attached as Appendix B. 
Bain and Overend say:

A number of gasifiers that have the potential to be suitable for the electricity production are under development in the United States. These systems are operated at the 4-to- 25 tpd (ton/day) scale. In addition, a number of small commercial systems are being operated in the United States to produce low-Btu gas as substitute fuel or for steam cycle electricity production.

According to Bain and Overend, the DOE-established R\&D objectives, beginning fiscal year 1991, are as follows:

- Start to develop hot gas cleanup systems to link gasifiers and turbines, with special emphasis on investigating alkali metal transport in gasification and combustion systems.

- Manage the scale-up of IGT's Renugas pressurized air/oxygen fluidized bed gasifier from its present capacity of 10 tpd to 100 tpd in the DOE cost-shared program with the PICHTR in Hawaii.

- Work with IGT and turbine manufacturers to develop hot gas cleanup at the 10 tpd scale so that a test by a MW turbine can be installed on the PICHTR unit in 1994.

- Monitor, in conjunction with EPA and Winrock International, the assessment of a fixed-bed pressurized gasifier for turbine applications on various biomass fuels.

- Undertake an evaluation of the potential bio-crudes produced by pyrolysis for use as gas turbine fuels.

- Manage funds for a joint evaluation, with industry, of a 50- to $100-\mathrm{MW}_{\mathrm{e}}$ commercial demonstration of an advanced-cycle power generation system.

- Manage, in conjunction with DOE fossil energy, a program for the design, construction, and operation of a $500-\mathrm{kW}$ gas turbine direct-fired by a wood combustor.

It is worthwhile to review the PICHTR/Hawaii project. Bain and Overend say the project objective is to demonstrate that the BIG/GT system can produce electricity from either bagasse or wood. The project has two phases. The first involves the design, construction, and operation of a 100-tpd gasifier based on the IGT/Renugas $®$ process. That technology has been developed only to the 20-tpd stage, by IGT of Chicago as the project and process developer. Upon successful scale-up, the second phase will incorporate hot gas cleanup and eventually gas turbines in the operations. NREL project managers are negotiating with Westinghouse to integrate the Westinghouse ceramic filter clean-up technology for application with the IGT gasifier. The timing for both phases is 2 years for design and construction, including 1 year to produce processed gas fuel and 1 year to evaluate hot gas cleanup and integrated turbine performance. According to Bain and Overend:

It is anticipated that alkali transport and hot gas clean-up unit lifetime will be the major technical challenges in this program. Therefore, in support of plan Phase II effort a request for proposal will be issued in FY 1992 to evaluate hot gas clean-up at the 10 tpd scale. If this program is successful, it is expected that this technology will be at the commercialization stage in about 4-1/2 to 5 years.

In summary, ongoing R\&D at DOE to remove obstacles and develop the potential for biomass in the production of electricity has identified major technical challenges and a systematic program to address and remove those obstacles. NREL has identified areas of technical concern but not any substantial new 
technology development or R\&D efforts. An advisory group assembled by the EPA was asked whether any critical steps to the commercial application of gasifiers with gas turbines had been taken. The results of that analysis are attached as Appendix C. As shown earlier, the Renugas ${ }^{\circledR}$ technology, utilizing fluidized bed and hot gas cleanup, is only one technology path that can be taken to obtain a sufficiently clean and cost-competitive producer gas from the gasification of biomass. A major part of the economic analysis for this project is trying to balance the technological promise and the economic promise of various gasifier technologies. The ongoing program managed by NREL offers a floor that clearly shows great opportunity for the commercial application of biomass in advanced or high-efficiency systems.

The Future Energy/Battelle process has several important advantages which, even in the absence of Future Energy's financial commitment, would strongly recommend it for utilization with aero-derivative turbines. The technology has been developed and tested over a decade on a number of biomass feedstocks, including wood chips and switchgrass. Because it was designed for the higher volatility of biomass, initial capital requirements are low. DOE is about to begin testing a small $200-\mathrm{kW}$ turbine integrated with the 10-tpd design gasifier at the Battelle Laboratory in Columbus, Ohio. These tests will show the operational capabilities of the cleanup process and will be finished before construction is undertaken at the 200-tpd unit. If successful, the tests will reassure developers about the reliability of the technology. Further commercial-size testing will begin before integration with a commercial-scale turbine.

The Future Energy/Battelle gasifier offers a technological alternative to the IGT/Renugas® technology. Moreover, the proposed development path of this project offers an alternative to the more conservative path chosen for the PICHTR project. If all phases are successful, this project could be operational by 1996 or 1997 . The possibility of rapid program development is an important benefit. 


\section{Joint Ventures to Advance Technology}

\section{A. Nature of the Proposed Joint Venture}

Public Law 101.218, signed into law on December 11, 1989, provides the general framework under which the development and demonstration of BIG/GT technology is evaluated. That act lays out the interest of the federal government in renewable energy technologies and the conditions under which joint federal/nonfederal efforts to develop and demonstrate technologies can be undertaken; it broadly defines the economic relationship between federal and non-federal participants.

That framework is augmented in the Energy Policy Act of 1992. The box below shows requirements considered by DOE for participation in joint ventures. The Energy Policy Act authorizes a $\$ 50 \mathrm{M}$ fund for use in joint ventures.

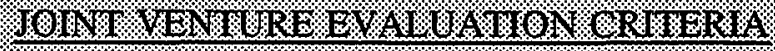

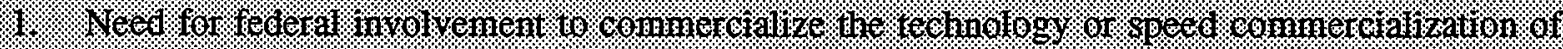

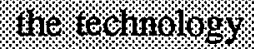

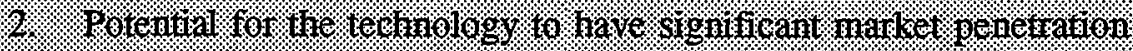

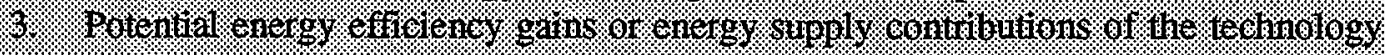

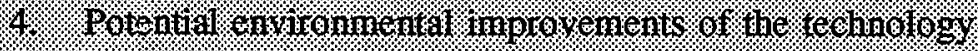

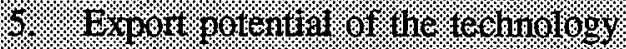

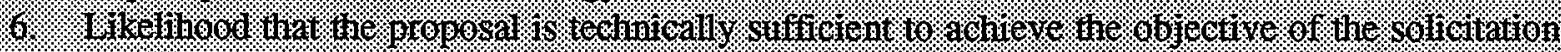

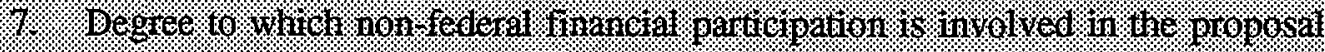

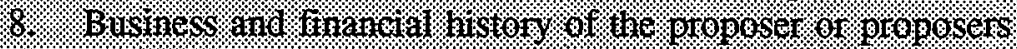

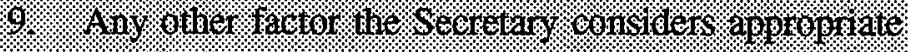

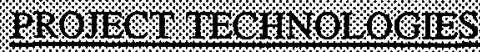

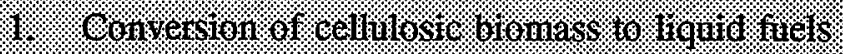

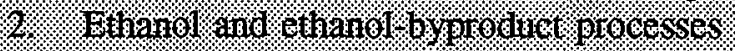

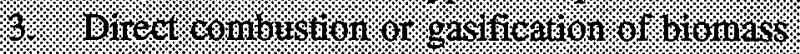

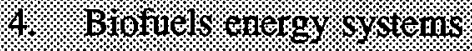

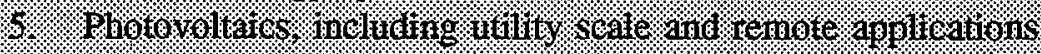

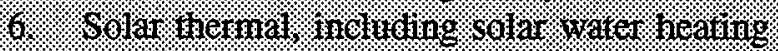

1. 1 . Wind.ene.g.

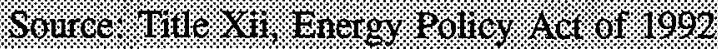

As originally perceived, the purpose of authorization for joint ventures was to "pursue an aggressive national program of research, development and demonstration of renewable energy and energy efficiency technologies in order to insure a stable and secure future energy supply." ${ }^{16}$ In the intervening period, interest in development of joint ventures to pursue environmental benefits has grown. While the basic structure has remained largely the same, the analysis of the public interest and the reasons for federal participation, as presented in this report, include consideration of a national interest in the development 
of technologies that can mitigate or remove the environmental consequences of energy use. Under Public Law 101.218 and the Energy Policy Act of 1992, the key definition is that of a "joint venture." In the initial act, joint venture was defined as "any agreement entered into under this act by the Secretary with more than one or a consortium of non-federal persons. . .for costs shared, research, development or demonstration of technologies. .." A non-federal person could be any entity located in the United States or any locality where the controlling interest is held by U.S. citizens.

Although no actual projects have been undertaken, discussion and analysis have been developed so that a fairly well-defined understanding of joint ventures has been produced. Joint ventures are a way to demonstrate technologies that have already passed through the R\&D phase. When the technology is ready for demonstration, its ability to establish commercial viability will carry an extra risk or series of risks, whose costs are not easily or appropriately borne by private business or non-federal persons. The extraordinary risks of commercial development can appropriately be borne by the federal sector to move the technologies closer to commercial application. For this to happen, the technology must demonstrate commercial potential. A critical concept in joint ventures is that the appropriate non-federal interest should roughly correspond to the amount of investment required in an on-going commercial venture. The federal role is to reduce the one-time development risks to allow for a viable demonstration project. As an additional condition, the Act stated that cost sharing implied that "the Secretary shall require at least $50 \%$ of the costs directly and specifically related to any joint ventures under this section ... to be provided from non-federal sources."

Public Law 101.218 laid out a set of technology priorities for wind, photovoltaic, solar thermal, and geothermal projects. The Energy Policy Act of 1992 also allowed for additional joint ventures. The Act identified findings that were generally positive attributes expected to occur from joint ventures, including early or more rapid commercialization of technology that can also increase the competitiveness of U.S. fir ms in international trade.

\section{B. Public Participation in the Joint Venture based on an Expanded Assessment of Competitive Potential and Environmental Benefits}

The federal purposes for participating in joint ventures probably should be expanded to include attainment of environmental benefits. As the federal interest in integrating energy and environmental policy grows, joint ventures offer an important way for federal policy to advance that goal. In particular, as the federal concern with greenhouse gases and increasing concentrations of $\mathrm{CO}_{2}$ in the atmosphere grows, the importance of finding technologies that are neutral with respect to $\mathrm{CO}_{2}$ should increase. The increased efficiency of energy use through deployment of technologies and the reduction in uses that would result from higher energy prices can only go so far toward attaining those goals. This is particularly true if one recognizes that the goals must be global to have any meaning at all.

Since efficiency can only be a step toward those goals, the deployment of technologies that can meet energy needs without aggravating environmental problems and without contributing to increased concentrations of $\mathrm{CO}_{2}$ in the atmosphere should be an important component of any plan to meet $\mathrm{CO}_{2}$ stabilization objectives. Taxes on carbon emissions can be effective in influencing investment and usage decisions to attain those goals. Regardless of what one thinks about the desirability or viability of carbon taxes, having more options for shifting from technologies that contribute carbon concentrations to the atmosphere will increase the effectiveness of carbon taxes or price-based policy options. One method is to identify the specific environmental consequences of advanced renewable technologies and use that evaluation as part of the rationale for federal participation in joint ventures. The environmental effects of energy use have been quantified and used as a resource selection fairly extensively at the state level. Table 1 shows externality values that have been proposed by several states for use in resource planning. 
Table 1. Comparison of Emission Externality Costs

\begin{tabular}{ccccc}
\hline & \multicolumn{5}{c}{ Units in \$/Pound } \\
\cline { 2 - 5 } Emissions & NY PSC & MS DPU & NV PSC & CA PUC \\
\hline $\mathrm{SO}_{\mathrm{x}}$ & 0.41 & 0.75 & 0.78 & 2.03 \\
$\mathrm{NO}_{\mathrm{x}}$ & 0.89 & 3.25 & 3.40 & 3.55 \\
$\mathrm{VOC}_{\mathrm{s}}$ & - & 2.65 & 0.59 & 1.65 \\
$\mathrm{CO}$ & - & 0.43 & 0.46 & - \\
Particulates & 0.16 & 2.00 & 2.09 & 1.19 \\
$\mathrm{CO}_{2}$ & 0.001 & 0.011 & 0.011 & 0.013 \\
$\mathrm{CH}_{4}$ & - & 0.11 & 0.11 & - \\
$\mathrm{N}_{2} \mathrm{O}$ & - & 1.98 & 2.07 & - \\
\hline${ }^{17}$ Source: Economic Research Associates, 1992 & & &
\end{tabular}

Considerable literature and debate exists on the quantification of those values. Several commentators have observed that regardless of the precise value placed on pollution, there is no argument that the values are not zero. States that quantify the values of pollutants from the conversion of fuels to electricity have used those externalities to adjust the resource selection process.

The same processes used for quantifying the environmental consequences of energy production can guide federal-level participation in joint ventures. At present, no federal assessment of the methodologies or values of externalities has been undertaken. For this analysis, we will not suggest firm values but simply outline how externalities can be expanded to justify a basis for public intervention in technology development. One original goal of federal-private joint venture was to hasten the commercial deployment of technologies that could play an important role in energy security. If the environmental benefits of a particular technology can be estimated, they also can be used to justify public participation or investment. It remains to be seen how the goals of security and environmental mitigation can be applied jointly to projects under consideration. Given the work done at the state level and by other nations, the initial step-the quantification of external values associated with energy use-should be relatively straightforward. If those external values can be calculated or an agreed-upon band of values determined, the first step in adding environmental consequences into the justification for public intervention is to estimate avoided pollution resulting from the deployment of this technology. The pollution avoided will have to be calculated for specific situations, a calculation not readily available for this report. However, an important analysis by the EPA looked at the reductions in air pollution indices that result from a variety of scenarios in which advanced renewable technologies are assumed to be developed and deployed, these data are presented in Table 2.

The EPA analysis can serve as an initial basis for the additional quantification of the avoided air pollutant values. One next estimates the saturation of the technology assuming a successful commercialization project is completed. Given the total expected saturation, the number of deployed megawatts are calculated and a total avoided pollution derived. The total yearly value of the avoided pollution that could be expected to result from a successful joint venture in this technology can be determined. As shown in Table 3, the expected payoff is substantial. If the initial public investment in a joint venture is roughly $\$ 1000 / \mathrm{kW}$, and the joint venture leads to installed capacity 100 times greater than the demonstration of $20 \mathrm{MW}$, the yearly payback is between 1 and 18 . 
Table 2. Electric Generation Costs and Air Pollution Prevented

\begin{tabular}{|c|c|c|c|c|c|c|c|c|}
\hline \multirow[b]{2}{*}{ Region } & \multirow{2}{*}{$\begin{array}{c}\text { Incremental } \\
\text { Generation } \\
1990-2010 \\
(G W h / y r)\end{array}$} & \multicolumn{7}{|c|}{$\begin{array}{l}\text { Air Pollution Prevented 1990-2010 } \\
\text { (thousand metric tons/yr) }\end{array}$} \\
\hline & & $\mathrm{SO}_{\mathrm{x}}$ & $\mathrm{NO}_{\mathrm{x}}$ & $\begin{array}{c}\text { Particulat } \\
\text { Matter }\end{array}$ & & & & \\
\hline Northeast & 11,181 & 52.4 & 8.6 & -1.78 & -16.00 & 0.08 & $8, \overline{173}$ & 8,470 \\
\hline Southeast & 35,206 & 267.5 & 76.1 & -2.82 & -50.60 & 0.30 & 33,068 & 35,966 \\
\hline Southwest & 5,402 & 6.4 & 9.1 & -1.09 & -7.68 & 0.02 & 3,894 & 4,235 \\
\hline North Central & 7,244 & 77.7 & 19.6 & -0.41 & -10.42 & 0.06 & 7,307 & 8,060 \\
\hline Northwest/Mountain & 8,996 & 54.0 & 26.2 & -0.24 & -13.00 & 0.09 & 9,539 & 10,550 \\
\hline Califomia & 8,702 & -0.7 & 6.6 & -2.47 & -12.33 & 0.02 & 4,628 & 4,857 \\
\hline TOTAL & 76,731 & 457.4 & 146.2 & -8.82 & -110.04 & 0.58 & 66,608 & 72,138 \\
\hline
\end{tabular}

It would be unrealistic to expect all joint ventures to be successful. The public gain, while obviously subject to some margin of error, supports public intervention and the investment of public funds in the commercial development of that technology. An additional approach would be to calculate the environmental benefits on the basis of per- $\mathrm{kW}$ of installed capacity and per-kWh of electricity generated. This would involve many of the calculations discussed above but would include the "cost" of public funds used to produce electricity with no $\mathrm{CO}_{2}$ emissions. This calculation uses the saturation estimate of 100-to-1. An outline of this process follows.

\section{Options for $\mathrm{CO}_{2}$ Stabilization}

Energy and environmental policies can be integrated to stabilize $\mathrm{CO}_{2}$ emissions by using three approaches:

- The efficiency with which we use energy can be increased.

- Natural gas use can be increased.

- New technologies that break the link between energy production and environmental damage can be developed and deployed in the market.

Table 3. Valuing $\mathrm{CO}_{2}$ Reductions

\begin{tabular}{lc}
\hline Estimated Electric Production & $13,140 \mathrm{MWh}$ \\
Avoided $\mathrm{CO}_{2}$ (thousands of metric tons) & $12,353^{1}$ \\
Yearly Value: Low (at $\$ .001 / \mathrm{lb}$ ) & $\$ 27.2 \mathrm{M}^{2}$ \\
Yearly Value: High (at $\$ .013 / \mathrm{lb}$ ) & $\$ 353.3 \mathrm{M}^{3}$ \\
Internal Rate of Return (low value) & $136 \%$ \\
\hline $1 \quad$ Calculated using national total from EPA study, prorated for production from \\
$\quad 2000 \mathrm{MW}$ of BIG/GT production. \\
2 NY PSC external value for $\mathrm{CO}_{2} @ \$ .001 / \mathrm{bb}$. \\
3 CA PUC external value for $\mathrm{CO}_{2} @ \$ .013 / \mathrm{b}$.
\end{tabular}




\section{$\mathrm{CO}_{2}$ Stabilization As An Advanced Technology Goal}

Stabilization of $\mathrm{CO}_{2}$ can be aggressively pursued even without large carbon taxes. $\mathrm{CO}_{2}$ reductions can be an important public benefit and can be identified as such. Part of the risk of developing technologies to capture the public benefit can be underwritten in federal/private joint ventures. The following conditions apply:

- The technology must have demonstrated $\mathrm{CO}_{2}$ stabilization benefits.

- Market potential beyond initial deployment must be substantial, on the order of 100-to-1. Thus, the demonstration of $20 \mathrm{MWs}$ of a technology must be likely to lead to market development of $2000 \mathrm{MWs}$.

- Initial private participation must cover $50 \%$ of the project cost.

- Public participation must write down the unique costs of initial commercial deployment of advanced technologies, or provide $50 \%$ of the project cost-whichever is less.

\section{Project Benefits}

- As agricultural crop-support programs are phased out, energy crops grown or harvested on a sustained basis can revitalize local communities.

- The very high conversion efficiencies of the advanced technologies are critical to making this agricultural conversion happen without ongoing federal subsidies or higher retail electric prices.

- These technologies, developed and perfected domestically, will enjoy substantial world wide application as other nations join efforts to stabilize $\mathrm{CO}_{2}$ and other greenhouse gas emissions.

\section{Project Participation}

- Assume the market deployment potential for technologies is 100 to 1 , and public funding of $\$ 1000 / \mathrm{kW}$ is committed for public cost sharing of initial pre-commercial project development.

- The public cost of producing electricity with no adverse $\mathrm{CO}_{2}$ or other global warming consequences is $\$ .00015 / \mathrm{kWh}$ (assuming 100-to-1 deployment, 10\% discount rate, 75\% capacity factor, and 20-year life). 


\section{Project Economics}

In order to establish the commercial potential of the BIG/GT technology, an economic assessment of the mature, commercially developed turnkey economics should show that the cost of electricity produced from the technology is equal to or less than its avoided cost. It is important to distinguish between turnkey cost and first plant cost. Tumkey estimates assume that risks associated with project development have been removed and the technology is available at published commercial terms and operating conditions, i.e., on a turnkey basis.

Several factors dominate the turnkey cost calculation, including:

- Overall capital cost for turbine, gasifier, gas cleanup, wood yard, and fuel handling equipment

- Fuel cost (green and dry)

- Financial parameters that will be converted and used as capital recovery factors

- Generator conversion efficiency

- Gasifier conversion efficiency

- Gas cleanup cost

The turnkey plant cost estimate developed in Table S-1 shows the levelized cost of production to be $\$ 05.7 / \mathrm{kWh}$. While factors are subject to uncertainty, cost estimates show the technology to be competitive. This turnkey cost is below the avoided costs for Iowa and Vermont, states with substantial interest in the technology.

For Vermont, the most recent complete review found the levelized, 20-year avoided cost of electricity to be roughly $7.5 \mathrm{c} / \mathrm{kWh}$, a calculation sensitive to the long-term price of natural gas since the avoided unit was a gas combined cycle unit. The avoided cost factored in the price of short-term capacity and energy purchasers.

The evaluation of avoided cost was completed in 1991. Since then, lowered demand for electricity has driven down the short-run cost of capacity and has raised substantial questions about the need for capacity in the entire northeast. No utility will state with certainty when the next increment of capacity will be required. Several have indicated that the next critical juncture will come in 1998 when a large coal-fired contract comes up for renewal. It is likely utilities will either have to renew that contract or find replacements. A recent evaluation of long-run avoided costs for Vermont conducted for 1997 showed the 20 -year levelized avoided cost to be about $\$ 0.8 / \mathrm{kWh}$.

As a result of uncertainty about capacity requirements and the current avoided costs, a recommendation for Vermont is that any project be divided into phases, with a gasifier phase done first to reduce reliance on a long-run avoided cost estimate. In addition, while any long-run avoided cost estimate can serve as a threshold for determining market acceptability, further refinement of the operating characteristics of the technology must be developed and supplied to utilities as they make their own assessments about capacity requirements and resource choices. (See letter from Green Mountain Power to EPRI, attached as Appendix 4).

For Iowa, the assessment of the avoided cost is more straightforward. At the present time, the state has a law requiring the payment of $\$ 0.6 / \mathrm{kWh}$ for electricity generated from qualifying facilities that use renewable resources.

Most uncertainty in estimates of capacity costs for the development of turnkey busbar generating cases is attached to the fuel portion of the project, which includes not only the cost of the biomass but also 
equipment costs that include fuel lot and handling and gasifier and gas cleanup technology. Most turbine costs and operating characteristics are well-known; the only area of uncertainty concerns the cost of adapting the turbines to use gas of varying Btu content. The technical concerns over modifying the turbine in the Brazil project led to added cost, and Phase I funds had to be diverted for that purpose.

The Brazilian project broke out total capacity costs for the LM 1600 with bottoming cycle into fairly detailed investment categories, as shown in Table 4.

Table 4. LM 1600/Brazilian Demonstration Plant Investment

\begin{tabular}{lc}
\hline \multicolumn{1}{c}{ Equipment } & Cost Range (\$M) \\
\hline Wood Yard & 2.4 \\
Gasification Plant & 15.3 to 21.2 \\
Turbine & 7.9 \\
Bottoming Cycle & 3.4 \\
$\quad$ TOTAL & 29 to 34.9 \\
Fuel Related & 18.6 to 24.5 \\
Capacity Related & 10.4 \\
\hline${ }^{19}$ Source: Engenharia 1992. &
\end{tabular}

Roughly two-thirds of total capital costs are related to fuel handling and gasification. This is the area of greatest uncertainty with respect to operational characteristics, so great attention must be paid to the developmental risk.

Busbar cost estimates are developed as shown in Table 5; they display a considerable range.

The World Bank project developed the estimates (Table 6) of the cost of electricity from the first and the Nth plants, where the Nth plant represents the estimated potential of the technology on a mature or tumkey basis.

The World Bank and DOE estimates are the most fully developed. The EPRI numbers are initial estimates and subject to revisions and updating. They were obtained from a conversation with GMP, which has taken a leading interest in the development and assessment of this technology with EPRI. 
Table 5. Project Economics ${ }^{1}$

\begin{tabular}{|c|c|c|c|c|}
\hline & \multicolumn{3}{|c|}{ EPRI (Initial) ${ }^{2}$} & DOE (1st Plant) ${ }^{3}$ \\
\hline Capital Cost & \multicolumn{3}{|c|}{$\$ 2,000-\$ 3,500$} & $\$ 1,504$ \\
\hline Fuel Costs & \multicolumn{3}{|c|}{$\begin{array}{c}\$ 15-20 / \text { ton (green) } \\
(\$ 30 / \text { ton dry) }\end{array}$} & $\$ 17 /$ ton (green) \\
\hline O\&M & \multicolumn{3}{|c|}{$\$ 8-20 / M W h$} & $\$ 14.56 / \mathrm{MWh}$ \\
\hline Heat Rate & \multicolumn{3}{|c|}{ 9,000-11,500 BTU/kWh } & $11,059-9,545$ \\
\hline \multirow[t]{4}{*}{ Busbar Cost } & Capacity: & .0328 & -.0574 & .0247 \\
\hline & O\&M & .008 & -.020 & .0146 \\
\hline & Fuel & .018 & .023 & $.022-.0191$ \\
\hline & Total & .0588 & .1004 & $.0613-.058$ \\
\hline
\end{tabular}

${ }^{1}$ Assume $71 \%$ capacity factor and $10.2 \%$ CRF.

${ }^{2} \mathrm{EPRI}$ estimates are from conversation with GMP.

${ }^{3}$ Biomass to electricity.

Table 6. Brazilian Cost of Electricity Estimates

\begin{tabular}{|c|c|c|c|c|c|}
\hline Alternative & Type of Plant & $\begin{array}{l}\text { Power } \\
\text { MW }_{\mathrm{e}}\end{array}$ & $\begin{array}{l}\quad \text { Total } \\
\text { Investment } \\
\text { \$US (mill) }\end{array}$ & $\begin{array}{l}\mathrm{IRR}^{\mathrm{a}} \\
(\%)\end{array}$ & $\begin{array}{c}\text { Energy } \\
\text { Cost } \\
\text { \$US/MWh }\end{array}$ \\
\hline \multirow[t]{2}{*}{ LM 1600} & First-of-Kind & 18 & 49.5 & 8 & 80.2 \\
\hline & Nth Commercial & 18 & 27.0 & 8 & 54.4 \\
\hline \multirow[t]{2}{*}{ LM 2500} & First-of-Kind & 30 & 82.5 & 8 & 80.7 \\
\hline & Nth Commercial & 30 & 45.0 & 8 & 54.8 \\
\hline
\end{tabular}

${ }^{20}$ Source: Brazilian Biomass Power Generation.

The cost of electricity ranges from $\$ 05.4 / \mathrm{kWh}$ to over $\$ 0.10 / \mathrm{kWh}$ using the high EPRI estimate. Using the DOE and World Bank estimates, the range is much narrower and better supported by capital estimates and actual operating characteristics of the turbines. Data on the turbine from Stewart and Stephenson shows that the LM 1600 should be expected to have a heat rate of $9,545 \mathrm{Btu} / \mathrm{kWh}$. In addition, the firsttime capital estimates of the World Bank/Brazil project are less than the upper estimates supplied by EPRI. Based on World Bank and DOE estimates, turnkey cost estimates for this report of $\$ 0.057 / \mathrm{kWh}$ are reasonable for plants that are fully developed and operational. The conservatism of these estimates is supported by the expectation that the gasifier and cleanup technology can reduce capital costs. The Future Energy/Battelle process is estimated to cost $\$ 450-600 / \mathrm{kW}_{e}$, including cleanup cost. If this can be realized, the DOE capital costs would drop $20 \%$ to $30 \%$.

Overall improvements can come from lowering fuel costs, increasing system efficiencies, lowering capital costs, and/or reducing financial carrying costs. 
Fuel costs of $\$ 2 / \mathrm{MMBtu}$ green wood chips are assumed constant. Any negotiation should attempt to lock in this cost at a constant real-dollar value.

System efficiencies are available primarily by moving the technology along the development path from open cycle to steam injected, to inter-cooled. Of the two GE turbines, only the LM 1600 can accommodate this development.

System efficiencies are also available by increasing the megawatt size of the project. According to Stewart and Stephenson specifications, the LM 6000, a 42-MW plant in open cycle, has a heat rate of $8300 \mathrm{Btu} / \mathrm{kWh}$. This represents an improvement of nearly $15 \%$ over the LM 1600 . Two factors limit the usefulness of this increase. One is that as overall efficiency increases, the busbar generation cost diminishes. At $20 \%$ efficiency, the fuel cost of a $\mathrm{kWh}$ generated will be $\$ 03.4 / \mathrm{kWh}$. Increasing fuel efficiency to $35 \%$ will lower fuel costs to $\$ 0.019 / \mathrm{kWh}$ and contribute to bottom line economics by $\$ 01.5$. Raising fuel efficiency to $50 \%$ will lower fuel costs to $\$ 01.4 / \mathrm{kWh}$ and contribute only $\$ 0.5 / \mathrm{kWh}$ to the bottom line. As overall system efficiency increases, the improvement to the bottom line brought about by further efficiencies and reductions in overall fuel expenses will decrease. This should be closely monitored.

An additional drawback of achieving efficiency by increasing size comes with fuel procurement. The larger the plant, the larger the radius of the area from which fuel must be gathered. Larger plants may have large siting and permitting problems, since greater fuel demands could pose greater stress on the host community.

The choice of gasifier and gas cleanup technology offers an important option. The Future Energy/Battelle gasification/gas cleanup holds the potential of lowering capital costs but gives up some conversion efficiency. The marginal loss in fuel conversion is likely to be more than covered by the reduced capital costs of the Future Energy/Battelle process. Gasifiers can operate on an atmospheric or pressurized basis. Pressurized gasifiers offer greater system efficiencies but this efficiency comes at a cost penalty.

Ceramic candle filters seem to be the chosen technology for hot gas cleanup. A manufacturer ready to supply this technology says that the cost of ceramic filters is expected to run to $\$ 200 / \mathrm{kW}$, with additional operation and maintenance costs in the range of $\$ .001 / \mathrm{kWh}$.

Atmospheric gasifiers with quenched gas cleanup offer a less-efficient, but also a less-expensive technology option.

The most efficient system is not necessarily the superior economic system. The marginal economic retum to efficiency improvements declines as the system increases in efficiency. An efficiency improvement of $10 \%$ to $15 \%$ means more in kilowatt-hour terms in relatively less-efficient systems.

Under standard financial terms, the ceramic candle filters cost roughly $\$ 0.006-0.007 / \mathrm{kWh}$. If basic system efficiency improvements reduce fuel costs to $\$ 0.015-0.02 / \mathrm{kWh}$, the pressurized/hot gas cleanup must contribute an efficiency improvement of $30 \%$ or more to pay for itself. Since the total efficiency of the Battelle atmospheric system is estimated to be $75 \%$ or greater, an improvement of $30 \%$ seems unlikely.

Lowering overall capital cost could result from the choice of equipment. The Battelle gasifier, developed specifically for biomass, will require a smaller capital investment than gasifiers developed for coal. This technology could offer an important cost advantage. The Battelle process could be available for approximately $\$ 400-450 / \mathrm{kW}_{\mathrm{e}}$. 
Carrying costs can be reduced in a number of ways. For waste wood projects, up to $80 \%$ of financing can be obtained using tax-exempt industrial development bonds. If projects can be levered to $80 \%$ debt and the cost of that debt reduced by $2 \%$ to $4 \%$, cost can be drastically cut. A substantial portion of interest and support for the technology came from those most closely associated with the fuel. Environmental benefits of the technology flow mainly from the fuel and the fact that it is renewable; the same holds true for local economic benefits, because the fuel is locally grown. Providing for local interests in project development could give this technology an important advantage over other fuel sources.

Carrying costs also can be reduced by incentives, either at the federal or state level. Incentives potentially available range from bonus allowances under the CAA of 1990 to the provision of $\$ 01.5 / \mathrm{kWh}$ tax credit (or direct payment in the case of non-profits) for the production of electricity from certain renewables. 


\section{Development Risk}

\section{A. Identification and Quantification of Major Areas of Development Risk}

Any project involving the development of generation capacity and the sale of that capacity to ultimate end users involves normal business risks. This section attempts to categorize areas in which these development risks could accrue and makes a rough attempt at quantifying those risks.

These risks are, to a considerable extent, a function of the particular proposal under consideration. Costs associated with the development risks will vary depending upon the sites chosen. If a site already has fuel handling experience and permitting, development risks will be substantially reduced.

The types of risks fall into five categories: developmental, operational, financial, coordination, and fuel supply.

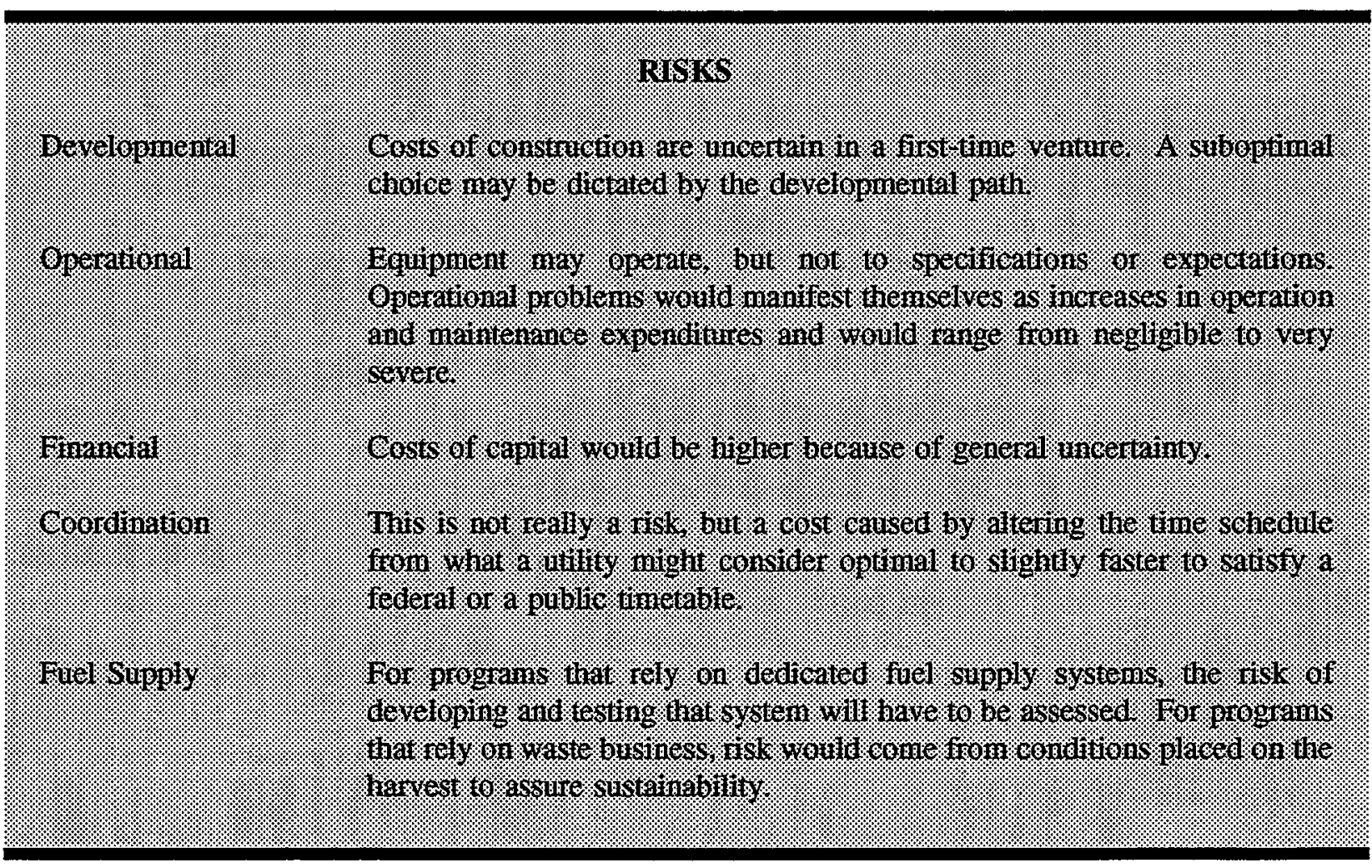

The developmental risks present the most severe financial impact. For the BIG/GT, the turnkey capital costs range from $\$ 900 / \mathrm{kW}$ to $\$ 1500 / \mathrm{kW}$ depending upon the estimates of gasifier, gas cleanup, and turbine costs. The greatest uncertainty attaches to the gasifier and gas cleanup. The aero-derivative turbines are an extremely well-known commodity and are available on a tumkey basis from a variety of manufacturers. The one uncertainty of the turbine is the modifications necessary to accommodate the particular Btu content of the gas produced from the gasifier. Even this uncertainty should be substantially reduced. With respect to the gasifier and the gas cleanup process, it seems prudent to anticipate that the first-time cost could be as much as $50 \%$ to $100 \%$ above the expected tumkey cost of the equipment. This cost will be greatly reduced if an initial project can be developed at a site with fuel handling and processing equipment in place. 
Operational risks are largely controllable by the structure of the development process. If the project were to propose a first-time venture at a green field site involving the integration of a gasifier and a turbine with no independent testing of the gasifier, operational risks would be substantial and could range from establishing fuel handling processes through anticipating the gas cleanliness and the suitability of the gas for using the turbine. The structure of the project can reduce these risks. In the worst case, the inability to use the gas produced could lead to no production of electricity and no return on investment. This would greatly increase the necessity for public financing. If the first venture can be structured to limit the exposure of the investment to where it can, with great certainty, be expected to produce electricity, initial risk is greatly reduced.

The ability of capital markets to recognize the public benefits of a project and support that project should not be overestimated. Without some provision of low-cost, tax-exempt economic development or other financing, the commercial cost of the capital for a project using an untested technology should be substantially greater than normal capital costs. In the assessment of turnkey economics, no explicit recognition of that factor was attempted. The only way to control this financial risk is to have in place either a certificate of public necessity (if developed by a private utility) or a power contract (if developed by an independent power producer). That power contract, in conjunction with the availability of a back-up fuel, will produce a fail-safe stream of revenue and capital cost recovery that can substantially protect bond and equity holders. Such protection provides an upper limit on the risk to non-federal participants and should increase their ability to raise money. If, for example, the project were to be developed in a state with a $\$ 0.6$ law for renewable projects, one could calculate the project cost that the private developer could realistically cover under a worst-case scenario. If financial costs drove the cost above that, it would not be economical for the private developer to participate without federal assistance.

Coordination risk is not associated with uncertainties in the technology but would arise from a different timetable to satisfy the public interest in developing the technology quickly (for example, if the particular utility or developer saw no need for additional capacity until 1999, but had interest in moving the technology by 1997). Coordination cost is associated with moving the construction and utilization of capacity forward a number of years. This financial calculation could easily be ascertained.

Fuel supply risks are especially severe for projects that anticipate using a dedicated fuel supply system. It is not anticipated that the initial project will use a dedicated fuel supply system, but rather will use wood chips from forest residues or waste wood. However, an important and immediate follow-on should be to develop markets for switchgrass. There, the requirement of developing a dedicated fuel supply system is substantial. Public risks involve the costs of determining how the particular fuel system should be grown, harvested, and stored, including considerations such as the kinds of payments necessary to the agricultural community to make the transfer from traditional to fuel crops.

\section{B. Financial Framework for Project Assessment}

It is important to consider the overall framework under which financial analyses can be undertaken. The basic difference between joint venture and traditional development projects is the unique commercial development risks of the project. The prior section attempted to categorize and quantify that risk. This section presents a structure of financial analysis that allows direct consideration of the level of risk, along with other financial variables, to determine overall project feasibility. The profitability of a project is a function of the avoided cost, the fuel cost, and the capacity cost of the technology. The traditional financial analysis constructs an internal rate of return, given some estimate of those measures. Using the standard financial analysis presented below, it is possible to develop a return on equity. The level of equity can be adjusted to reflect levels of risk or risk buy-down. An analysis of this type allows a consideration of the level of federal participation beyond that which can be ascertained in direct negotiations with developers. If the particular avoided cost is known, the return-to-equity participants can 
be determined for a variety of risk levels and/or risk buy-down. While no specific numbers have been attached to this analysis, it is a relatively straightforward process to make those estimates and use them in the negotiation associated with the development.

\section{Summary}

This analysis provides a financial methodology to be used to construct a cash flow and revenue stream for a generic BIG/GT electric generation project. The methodology can be used to solve for a $\$ / \mathrm{kWh}$ rate or an internal rate of retum on a presumed equity investment. The equity investment can include consideration of one-time cost elements. The structure of the analysis isolates the unique risks of initial project development, assesses the cost of those risks in terms of the IRR??? of the project, and determines the cost of the risk write-down. The analysis will require estimates of fuel cost, avoided costs, capital structure, cost of debt (and equity, if a $\mathrm{kWh}$ rate estimate is desired), gasifier cost and efficiency, cost of turbine and heat rate, capacity factor, and the quantification of initial development risk. The study will look at sites that vary considerably with respect to basic inputs and risk assessment. This analytical structure is intended to provide a basis for comparing and ranking projects.

\section{Fuel Cost}

$[\$ /$ ton $] /[$ Btu/lb] $=\$ /$ Btu

Assume green wood costs $\$ 17 /$ ton-at a fix equivalent cost of $\$ 2.00 / \mathrm{MMBtu}$.

Heat value $=\$ 2 \mathrm{MMBtu}$

\section{Running cost}

$[[\$ / \text { Btu }] /[\text { Gasifier Efficiency }]]^{*}[$ Btu $/ \mathrm{kWh}]=\$ / \mathrm{kWh}$

Assume $75 \%$ efficiency of gasifier, $9545-\mathrm{Btw} / \mathrm{kWh}$ efficiency at generator.

$[[\$ .000002 / \mathrm{Btu}] /[.75]] * 9545 \mathrm{Btu} / \mathrm{kWh}=\$ .02538 / \mathrm{kWh}$

\section{Capacity Cost}

$[\$ \mathrm{~kW} /$ Year $]=[[\$ \mathrm{~kW}] * \mathrm{CRF}]$; where CFR is the capital recovery factor. The CRF is a function of the cost of capital, depreciation, income tax, and any other appropriate cost associated with carrying investment. $\$ / \mathrm{kWh}=[\$ \mathrm{~kW} / \mathrm{yr}] /[8760 * \mathrm{FR}]$

Note: Capacity cost estimates can be developed two ways. The first involves using debt cost only, along with depreciation and other canrying costs. This cost estimate, along with running costs, makes up the expense of the project. If the revenue stream is known, as it would be if the project were a qualifying facility (QF) that had obtained an approved power contract, the analysis will solve for the internal rate of retum for the project. Alternatively, the capacity cost can be estimated using an implied cost of equity. In that case, the complete $\$ / \mathrm{kWh}$ can be estimated.

\section{Revenue Stream}

Revenue/yr $=[\$ / \mathrm{kWh}] *[8760 *$ Capacity factor $]$; where $\$ / \mathrm{kWh}$ is a levelized Public Utilities Regulatory Policies Act (PURPA)-avoided cost rate. 


\section{Return}

Equity $=[\$ / \mathrm{kW}-\mathrm{debt}]+\mathrm{risk}$

Net revenue $=$ [revenue/yr]-[running+capacity cost]

$\mathrm{RR}=\mathrm{f}$ [equity, net revenue, risk]

Note: Equity can be adjusted as a function of risk and is also a residual of the installed cost per kilowatt less the debt portion of the project. This structure is amenable to the joint-venture concept since it allows risk write-down to be directly calculated. The equity at risk in a commercial project is substantially greater than in a turnkey project. This analysis would first construct an assessment on a turnkey basis, then add a measure of the known risk to the equity portion of analysis. If the underlying principle is to provide a normal return on equity, this model will allow the assessment.

\section{Incentives Beyond Joint-Venture Financing}

A variety of federal incentives beyond joint-venture financing exist for certain renewable projects, including biomass gasification. The most important is the incentive available under the Internal Revenue Code, Section 29, for a tax credit for the production of gas from biomass. Other major incentives come from various tax incentives in the Energy Policy Act of 1992, such as that in Section 1212 which calls for the payment of $\$ 01.5 / \mathrm{kWh}$ for a 10 -year period adjusted for inflation for generation from certain renewable projects. Finally, there are credits available to renewable projects in the CAA of 1990 . The amendments award certain bonus allowances to renewable projects and, given the relatively low $\mathrm{SO}_{\mathrm{x}}$ emission from renewable fuels, provide the potential for a commercial advantage.

States also can provide incentives. State tax-exempt industrial development financing has been available for projects that use waste wood. If up to $80 \%$ of the financing can be provided by tax-exempt state bonds, that advantage can provide a leveraged benefit to equity owners for any given purchase price of electricity. Through regulatory commissions, states can also make a specified avoided cost available for certain renewable projects. The State of Iowa has a law to provide for the purchase of power from renewable projects at $\$ 0.6 / \mathrm{kWh}$. No calculation of the differential between the $\$ 0.6$ price and the actual long-term avoided cost has been found. Nevertheless, the assumption is that the difference is significant enough to encourage projects that would not otherwise come forward.

Before assessing the precise economic effect of the various incentives, two threshold issues have to be addressed. First, the existence of federal incentives does not automatically mean incentives will be available. The best example is that various sections in the Energy Policy Act of 1992 calling for a $\$ 1.5 / \mathrm{kWh}$ credit have no funding appropriation attached. Additionally, many incentives are offered as tax credits and their usefulness is limited by alternative minimum tax calculations. The second issue is how to assess incentives in determining the underlying commercial feasibility of the joint-venture technology. Our recommendation is to note the incentives and consider their presence in the structuring of any joint venture, but to not explicitly include them in the financial evaluation. The underlying purpose of the incentives is to provide an additional financial push for the development of renewable fuels and the displacement of fossil fuels. We would urge that purpose be expanded to include standard optional economics and joint-venture economics.

\section{Internal Revenue Code, Section 29}

\section{Tax Incentive/Non-Conventional Fuels: Gasification}

- A tax credit of $\$ 5 / b b l$ equivalent is available for gasifiers. 
- A $20-\mathrm{MW}$ project running at $75 \%$ capacity would require $1.12 \times 10^{12}$ Btu or roughly 200,000 barrel equivalent (assuming 5,800,000 Btu bbl).

- This project would create a tax credit of $\$ 1$ million per year.

Note: At this time, this credit is extended for projects that come under contract by 1996 . Credit is available until 2008. Credit is reduced for federal grants and state and local tax-exempt financing.

The tax incentive for non-conventional fuels for a $200-\mathrm{MW}$ project running at the industry average capacity of approximately $75 \%$ could generate tax credits of one million dollars per year. The availability of this credit is subject to conditions pertaining to the separate ownership of a gasifier facility and other factors. Nevertheless, one can expect the tax incentive to be available for a gasifier closely coupled to a turbine. The benefit would, to some extent, be available or allocatable to non-profit participants such as municipalities. This evaluation should be carried forward if this project proceeds. The importance of establishing the terms and conditions of availability for this credit are critical because, of all incentives available for this technology, this has the greatest ability for actual capture by the project.

\section{Energy Policy Act of 1992}

\section{Tax Incentive: Title XIX, Sec. 45, Tax Incentive for Certain Renewable Resources}

- Provides $\$ 0.015 / \mathrm{kWh}$ incentive for closed-loop biomass systems.

- Credit is reduced for grants, tax-exempt bonds, subsidized energy financing, and other credits.

- Payment to private utilities.

- Credit is reduced by reference price.

The Energy Policy Act of 1992 provides two similar incentive payments for renewable projects. Title XIX, Section 45, provides a tax incentive for renewable resources, but the credit is available only for "closed-loop" biomass systems. The credit is reduced for grants, tax-exempt bonds, subsidized energy financing, and other credits. These conditions limit the importance of this incentive when the crop is wood chips. Under most specific projects, proposals for fuel supply rely upon wood chips provided as waste wood. No early projects anticipate wood chips would be grown on a dedicated fuel supply plantation or a closed-loop basis. Also, this credit is reduced for "grants, tax-exempt bonds, subsidized energy financing and other credits." Since this project is to be developed as a joint venture, with roughly $50 \%$ federal participation in the initial plant development costs, this condition would reduce credit by up to $50 \%$ just from the participation of federal agencies. To the extent that the credit reduction is legitimate, it seems to rely on the idea that there should be no double dipping for incentives. Projects that use off-ofthe-shelf technology but may have federal grants or tax-exempt bonds should not be entitled to additional incentives. This does not seem to anticipate the specific problems that arise from first-of-a-kind or development projects like those envisioned here. To penalize joint-venture participants by reducing additional credit is to work at counter-purposes to the joint-venture legislation and a larger federal policy that should be involved in the development of renewable resources. Both incentive positions in the Energy Policy Act having to do with renewables operate against or in counter-purpose to the joint-venture intent.

\section{Energy Policy Act of 1992}

\section{Tax Incentive: Sec. 1212, Incentive Payments}

- Payment is to be $\$ 01.5 / \mathrm{kWh}$ for a 10 -year period, adjusted for inflation.

- There are no limiting factors for biomass, except for "burning of MSW." This would seem to allow for gasification.

- Payment to municipal utilities or other public utilities 
- Payments for $20 \mathrm{MW} @ 75 \%$ would be $\$ 1,971,000$ per year.

Note: At this time, this incentive is not reduced to reflect federal grants or state or local tax-exempt financing. However, this section has no current appropriation.

The same type of provision for private fims through the $\$ 01.5 / \mathrm{kWh}$ tax incentive is available to nonprivate or public owners of renewable projects in the forn of $\$ 01.5 / \mathrm{kWh}$ payment. The provision of this $\$ 01.5 / \mathrm{kWh}$ is not subject to the condition of a renewable crop from a closed-loop system. Unfortunately, at this time there is no appropriation to make this $\$ 01.5 / \mathrm{kWh}$ payment to public owners of renewable projects. Based on a $20-\mathrm{MW}$ project operating at a $75 \%$ capacity factor, this $\$ 01.5 / \mathrm{kWh}$ payment would be worth $\$ 1.971$ million each year for 10 years.

\section{Clean Air Act Amendments of 1990}

\section{Allowance Incentive}

- A bonus allowance is granted for every $250,000 \mathrm{kWh}$ generated using renewable energy.

- The bonuses are available from 1993 to 1995 or until the total original allotment is used up.

- The total value of this bonus is on the order of $\$ 100,000-\$ 230,000$ per year depending upon the resale value of the allowances earned.

Table _ shows how the bonus allowances available under the CAA of 1990 could provide additional credits up to $\$ 230,000$ per year, depending upon the resale value of the allowances earned. Right now, the availability of these bonuses is dubious. The bonus allowances are available for both conservation and renewable programs. The early development of the conservation programs may mean they will gather a line share of the bonus allowances available from the Amendments. Since biomass fuel is low in $\mathrm{SO}_{\mathrm{x}}$ emissions, biomass production should enjoy an economic advantage over fossil-coal based technology, which emits $\mathrm{SO}_{\mathrm{x}}$ and will have to purchase allowances for additional generation. Because the nature of this advantage will vary depending upon the fuel, the variety of different advantages that would flow to biomass have not been calculated. 


\section{Equipment Manufacturers}

\section{A. Turbines}

General Electric, Rolls Royce, and United Technologies manufacture aero-derivative turbines. GE and Westinghouse manufacture industrial turbines, which also are used to produce electricity. DOE and NREL are investigating the suitability of biomass gasification applications with 50-MW industrial turbines, focusing on the application of the gasifier integrated with aero-derivative turbines. In part, the attraction of the aero-derivative turbine is its relatively small power rating, which allows a lower demand for fuel and more modest harvesting and shipping requirements. In addition, the particular generation of aeroderivative engines being considered offers a relatively uniform efficiency. The smallest aero-derivative engine, the GE LM 1600, a 15-MW unit, has a heat rate (according to Stewart and Stephenson Publications) of $9545 \mathrm{Btu} / \mathrm{kWh}$. The LM 2500, a 29-MW unit more than 50\% larger in size than the LM 1600, has a heat rate of $9280 \mathrm{Btw} / \mathrm{kWh}$. This nearly identical heat rate is very unusual in the generation of electricity. The rule of thumb in generation was that economies of scale were substantial, and larger projects more than justified themselves through increased efficiency. If the aero-derivative turbine offers essentially the same heat rate for sizes down to roughly $15 \mathrm{mw}$, the technology would have an important benefit, in that it could be incrementally increased at relatively discrete sites.

GE is not the only manufacturer of aero-derivative turbines, but it is actively pursuing aero-derivative technology, not only in the open cycle but in the steam-injected and steam-injected inter-cooled applications. The LM 1600 has an important advantage over the LM 2500: it can offer inter-cooling.

The GE LM 1600 is derived from the F404 fighter jet engine. As a generator set, it produces $13,440 \mathrm{~kW}$ at a heat rate of $9545 \mathrm{Btu} / \mathrm{kWh}$. A fuel rate this low normally is associated with turbines much larger than the LM 1600. As the LM 1600 is the most fuel-efficient gas turbine in its class, the list of LM 1600 installations is expanding rapidly.

The LM 2500 industrial gas turbine, GE's most experienced aero-derivative engine, is derived from the TF-39 flight engine used for DC-10 jets. More than 1,000 LM 2500s are in land and marine service, with over 4 million hours of industrial operation. The LM 2500 has documented industrial availability exceeding $99 \%$.

The two-shaft LM 2500 can be operated at 3000 to $3600 \mathrm{rpm}$, allowing direct coupling of its power turbine to $50-\mathrm{Hz}$ or $60-\mathrm{Hz}$ electric generators. This avoids the gearbox required by most gas turbines and magnifies the reliability and heat rate advantages of the LM 2500. The fuel efficiency is also an advantage over geared units. Packaged as a generator set, the LM 2500 produces $22,800 \mathrm{~kW}$ at a fuel rate of $9280 \mathrm{Btu} / \mathrm{kWh}$. A variety of customized fuel nozzles are available for the LM 2500 for dual fuel, water injection, and steam injection applications. The steam-injected LM 2500 STIG 50 can accommodate $50,000 \mathrm{lbs} / \mathrm{hr}$ of steam injection for plants with fluctuating process loads. The STIG 50 produces $28,050 \mathrm{~kW}$ and eliminates the need for combined cycle equipment, such as steam turbines and condensers.

\section{B. Gasifiers}

The Clean Coal program has encouraged development of an integrated gasifier combined cycle technology to utilize coal as the feedstock in the gasifier. Several technologies have been developed that have attempted to solve the simultaneous problems of gas cleanup and, for coal, sulfur removal, in order to produce a technology suitable for wide-spread commercial application. The significant differences between biomass and coal as a feedstock appear to have an important effect on the design of gasifiers. 
It is feasible to use a biomass feedstock in a gasifier designed primarily to utilize coal; the Vermont/GE study adopted that approach. The test gasifier at the GE Schenectedy facility was a Lurgi/fixed-bed gasifier developed for the Clean Coal program. Despite that parentage, the gasifier was adapted to run on a pressurized basis and utilize wood chips and bagasse. In assessing gasifiers, the attached chart shows important requirements.

For the Biomass to Electric Program and the current project to have widespread application, either a particular gasifier or a family of gasifiers must be capable of handling the range of biomass resources, from wood chips (a fairly dense, relatively uniform sized product) to agricultural waste (which is much less dense and more random in size). The requirements for fuel entering the gasifier vary. This can be a function of a feeding process or can be built into the design of the gasifier.

Most gasifiers reviewed produced a low-Btu gas, with an energy content of $100-175 \mathrm{Btu} / \mathrm{ft}^{3}$. By comparison, natural gas averages approximately $1000 \mathrm{Btu} / \mathrm{ft}^{3}$. Most turbines available for electricity generation use the high Btu or natural gas-equivalent type of fuel. A few gasifiers evaluated produced a medium-Btu gas, ranging from 400 to $600 \mathrm{Btu} / \mathrm{ft}^{3}$. If medium-Btu gas can be produced economically, without using oxygen blown processes, it offers a significant advantage over low-Btu gas because it requires less modification of the turbine. In addition, the reduced modification permits a much more easily adapted process, capable of using gasifier-produced gas or pipeline gas. Since the gasifier will, at best, be subject to periods of outages and maintenance and, at worst, to systematic problems with fuelhandling or continuing operations, the ability to switch to pipeline gas offers an important risk reduction and financial support for the project. As long as the project generates electricity, it can earn money and pay down its capital cost under most power contracts or regulatory arrangements. If the project is designed to run only on gasifier-produced gas, and if the expected capacity is low, the overall risk rises. Thus, the ability to produce and use medium-Btu gas is an important advantage.

Operating conditions on gasifiers vary depending on whether they were designed to run on a pressurized or atmospheric basis. Pressurized gasifiers offer increased efficiency because the gas will not have to be compressed for use in the turbine. The corresponding disadvantage is the need for relatively more expensive equipment and design. It appears impossible to make a definitive evaluation, since the relative advantages of each gasifier involve trade-offs and are somewhat specific to the technologies evaluated, the efficiencies gained, and the cost penalties incurred.

Of all issues facing gasifiers, the economical cleanup of the gas to the point where it is suitable for use with a turbine is the most critical. All studies point to the probability that the gas produced can be cleaned up by using a variety of hot gas strategies or by quenching or cooling the gas and cleaning it with a more traditional technology. Hot gas cleanup must be done with a series of cyclones, which separate out particulate matter, or with ceramic filters, which are more effective but more expensive. Quenched gas cleanup is simpler but drops the overall efficiency of the system. In evaluating quenched gas, the efficiency penalty must be evaluated in the context of the overall efficiency achieved by the aeroderivative turbine. As the overall efficiency of conversion increases, the advantage of marginally increasing the efficiency drops in terms of its ability to reduce the cost of the kilowatt-hour produced. Accordingly, as efficiency improves, the fuel savings used to justify the expense of the cleanup technology decreases. While cyclone technology is relatively inexpensive, the gasifier used in the Vermont/GE test showed an inability to remove all particulates necessary to produce a gas to be used with turbines. On the other hand, ceramic filters appear to be available and quite capable of doing the job, but, according to some estimates, cost as much as $\$ 200 / \mathrm{kW}$ of installed capacity and entail an operation and maintenance cost of approximately $\$ .001 / \mathrm{kWh}$ produced.

Given the overall efficiency of the turbines, it would appear quenched gas could be very competitive with hot gas cleanup as long as the penalty was not greater than the $30 \%$ decrease in operating efficiency. The 
precise answer depends on particulars of the technology and the economics of the gasifier and cleanup strategy. The process for gasification developed at the Battelle Laboratories and licensed to Future Energy Resources has several significant characteristics that recommend it for application with aero-derivative turbines. An early assessment of its potential for applications in the 50-MW size is attached as Appendix 6.

Table 7

\section{Gasifier Technical and Commercial Evaluation}

I. Fuel requirements

- Types of fuel handled

- Requirements for fuel

- Sizing

- Moisture content

- Adaptability for multiple fuels

II. Produced gas

- Medium Btu

- Low Btu

- Other products

III. Operating condition

- Air or oxygen blown

- Pressurized

- Atmospheric

IV. Cleanup

- Hot gas

- Cyclones

- Ceramic

- Other

- Quenched gas

V. Economics

- System efficiency

- $\$ / \mathrm{kW}$ elective for gasifier

- Cleanup cost

VI. Experience

- Commercial, to-scale operation

- Commercial, not-to-scale

- Licensed

- Process design scale

VII. Siting

- Air emissions

- Ash

- Waste water 
A complete assessment of clean-coal program gasifiers will be produced by Alternative Energy Development as part of a subcontract to this project. That evaluation is available on request. 


\section{Site Evaluations}

\section{A. Bennington County and State of Vermont}

The State of Vermont's interest in BIG/GT technology began as a combination of interests in the Department of Public Service and the Department of Forests, Parks and Recreation (which is interested in wood harvesting and management practices). Of all of the regions of the state, southwest Bennington and the surrounding counties had the most severely underutilized forest resource. The U.S. Forest Service and the Green Mountain National Forest Service, in undertaking a study for rural development through forestry, found that developing markets for low-quality wood in Bennington and the surrounding sixcounty area was of critical importance. The report stated,

Although land is productive, there are few markets for the overabundant low-quality wood. Compared to the northern half of the state, very little of the annual growth is harvested. . .only $30 \%$ of the annual growth in Bennington County is being cut. To sustain harvest levels without depletion of the forests, the annual cut should be equal to or less than the amount of annual growth. The current level of harvest in southwestem Vermont is sustainable and could be raised.

The assessment of the Bennington County area found that increasing the annual harvest would have positive secondary impacts. For example, developing markets for low-quality wood results in thinning that would enhance commercial productivity, improving tree form and the rate of stock growth. Although the use of wood chips as a fuel and the generation of electricity are not the only markets for low-quality woods, the relatively low capital costs and the accessibility of the region to transmission grids, plus the possibility of inter-connection and marketing of the product, made the use of wood chips a primary option.

The Bennington area has had a strong interest in obtaining a demonstration project using wood chips. BCRC???? is acting as a sponsor of the development effort. In April 1992, the BCRC submitted a proposal to the New England Power Company in response to an RFP for renewable energy projects. Although this solicitation was not successful, various parts have been attached (Appendix 5) as an example of the interest in the region.

The Vermont Department of Public Service is looking for sites to develop this technology. The effort to locate a development partner is being coordinated by the BCRC. Central Vermont Public Service (CVPS), Vermont's largest privately-owned utility, has been participating with the BCRC in trying to develop a project. CVPS is a valuable partner because it has identified unique advantages to locating the project in the region in addition to those identified by Forest Resources and Management staff. CVPS's analysis indicated that locating a $20-\mathrm{MW}$ facility in the region would delay or defer the upgrading of the transmission system to increase reliability. Although no precise dollar figures have been placed on the value of that transmission benefit, private discussions with CVPS and the Public Service Deparment indicate that such an advantage could be considered in siting and certificating a project.

The Vermont Department of Public Service remains an active and critical agent in developing this technology and is interested in eventually siting and permitting a number of 20-MW projects. Although no systematic assessment has been done for certificating processes, the Deparment has conducted several analyses of the state's comprehensive energy needs. Four or five 20-MW facilities using BIG/GT technology could be sustainably supported by the forests in the state.

Considerable uncertainty surrounds certification of the technology, in part because it marks a departure from proven generation technologies. The Department of Public Service has worked with Vermont's 
Agency of Natural Resources to identify critical issues for air and water permitting. No insurmountable problems have been identified and the more complete combustion possible with gasification has been noted as a potential environmental advantage. Nevertheless, permitting will require detailed assessment of air and water by-products of the gasification process.

The interest of the BCRC, the Vermont Department of Public Service, and various forestry agencies represents important support for a project in southwest Vermont. Two important hurdles remain. First, a private developer with an interest in investing substantial capital has yet to come forward. Although CVPS has expressed interest in cooperating, it has not made an actual development proposal. Additionally, the capital costs and project risks that stem from Bennington being a green field project cannot be overlooked. The development of a wood yard, the purchase of wood-handling equipment, the gathering of permits, and the experience of personnel in handling the fuel can burden an initial development project if it must be developed at a green field site. To go ahead with the project, Bennington would have to locate a wood yard, obtain wood permits and wood-handling equipment, and go through the necessary leaming curve of developing experience in handling the fuel. None of this is insurmountable. Once the fundamental questions about the technology's ability to deliver competitive electricity have been addressed, projects such as the one in Bennington County should be relatively easy to develop and permit. Whenever one is dealing with a first-of-a-kind project, however, additional costs can be an important consideration.

The interest of the state in multiple projects utilizing this technology should not be overlooked. It would be a grave mistake for Vermont or domestic projects to see the process of developing and proving the technology as one of competition among sites rather than cooperation. By utilizing the most ideally situated site to answer the critical questions surrounding the technology, the overall process is advanced to the greatest extent possible. The lack of a developer and infrastructure pose significant disadvantages for going ahead, yet the BCRC should continue to develop the project by taking the following steps:

- Locate several possible sites for a plant.

- Resolve issues associated with the location of a project, including truck traffic for wood delivery, transmission interconnection, water permitting, and air permitting.

- Continue to search for private developers to pick up the siting work of the regional commission and follow up to develop a 20-MW project.

- Cooperate in an initial demonstration project to quickly transfer the experience gained with the technology to a Bennington County project.

\section{B. State of lowa}

The project interest for the State of Iowa grows out of its search for sustainable, profitable energy crops. Iowa was an early cooperative participant with the State of Vermont in obtaining financing and support for the tests at the GE Research and Development Facility. Iowa provided switchgrass which, unfortunately, was not able to be processed through the gasifier. Switchgrass has been successfully gasified at the Battelle process development unit in Columbus. Following the GE project, Iowa inaugurated a collaboration among state agencies to pursue the development of energy crops, particularly switchgrass.

Two factors underline Iowa's commitment. First, the state faces substantial changes in federal crop support and productive land reduction programs, intensifying its interest in developing cash crops for energy. Second, given the present avoided cost of electricity for renewable energy sources, fairly high conversion efficiency is needed if the statutory structure is to yield sufficient income to the farm community to encourage it-without further federal or state subsidies- to switch to energy crop production. 
While the text on pages 30-32 describe the potential for the conversion of switchgrass into electricity and the extent of potential interest, it is also important to detail the work already underway that contributes to this project. The intent is to assess the important work already undertaken and the steps needed to make a transition to switchgrass crops and to use those efforts productively in this assessment.

Efforts are underway at Iowa and Iowa State University to assess the production capabilities for switchgrass and other supplemental energy crops that could be grown in a typical Iowa location. One main issue being investigated is the ability to ensure that the growth of switchgrass can be undertaken sufficiently to support the requirements of the technology. In addition, the studies assess the most costeffective ways to establish switchgrass crops using existing agricultural equipment. These efforts are important in controlling capital and one-time costs necessitated by the agricultural transition, and are expected to help make switchgrass available at the lowest cost possible.

Considerable investigation is being done on harvesting and storage techniques. Current studies are looking at 6-12 months storage and are determining the best procedures for balancing harvesting and storage to assure the availability of feedstock year-round. A study on advanced storage technique is being supported by NREL and undertaken by Iowa State University.

The Iowa Energy Center is preparing a state-wide omnibus study on the feasibility and potential of producing and converting many types of crops for energy, looking at the social, environmental, and technological aspects of this process. Most importantly, the study is attempting to draw a realistic bottom line on state potential.

This work is enormously important in preparing any area for conversion to the production and use of an energy crop. To capture the full potential of the gasification and gas turbine technology, this kind of preliminary analysis is essential. The relationship between the avoided cost of electricity, the particular conversion technology, and the net-back pricing for the crops ultimately depends upon an assessment of the available land and the management and harvesting practices for the use of that land. Without this kind of coordinated research and support, the transition to large-scale production of cash crops would be impossible.

Finally, Iowa has initiated a collaboration among a variety of public agencies for more than 2 years. This collaborative effort involves putting together a handbook on switchgrass, gathering all materials on how to establish the best management, storage, and maintenance programs and harvesting techniques, and other information on converting land to the production of switchgrass. The collaboration has also undertaken a review of old, unmanaged strands of switchgrass. Those analyses show relatively low yields and point to and underline the need to actively manage the production of this crop. The collaboration is working to assemble field-size tests to realistically test problems involved in the scale of production. At present, they estimate they will assemble 80 acres to test seeds and 120 acres to study methods for establishing switchgrass as a crop. According to state sources, 100 acres have already been assembled and reserved. 


\section{References}

${ }^{1}$ Energy Information Administration, Annual Outlook for Electric Power 1991, DOE, July 1991.

${ }^{2}$ Energy Information Administration.

${ }^{3}$ Renewable Electric Generation: An Assessment of Air Pollution Prevention Potential, March 1992.

${ }^{4}$ Phase One Final Report, P. 2, emphasis added

${ }^{5}$ World Development Report, 1992, p. 21.

${ }^{6}$ The Brazilian Biomass Power Generation Report, 1992, p. 1.

${ }^{7}$ Report, p. 20.

${ }^{8}$ Report, p. 4.

${ }^{9}$ Report, p. 33.

10

${ }^{11}$ Engenharia 1992, p. 26.

${ }^{12}$ Engenharia 1992, p. 41.

${ }^{13}$ UHDE

${ }^{14}$ Engenharia 1992.

${ }^{15}$ Much of this report is taken from Biomass to Electricity by R. Bain and R. Overend.

${ }^{16} 42$ U.S.C. 1202.

${ }^{17}$ Source: Economic Research Associates, 1992.

${ }^{18}$ Source: EPA 1992 , p. $10-25$.

${ }^{19}$ Source: Engenharia 1992.

${ }^{20}$ Source: Brazilian Biomass Power Generation.

${ }^{21}$ Developing Markets for Low-Quality Wood, p. 25. 


\section{Bibliography}

Anderson, D. (April, 1991). Energy and the Environment - An Economic Perspective on Recent Technical Developments and Policies. Prepared for The World Bank, Washington, D.C.

Anderson, D. The Energy Industry and Global Warming: New Roles for International Aid, Overseas Development Institute.

Bain, R.L., Overend, R.P. Biomass Gasification to Electricity; Fuels and Chemicals Research and Engineering Division, National Renewable Energy Laboratory (NREL), Golden, Colorado.

Bretz, E.A. (February, 1992). Clean-Coal Technologies: A Status Report; prepared for Electrical World.

CHESF (June, 1992). Brazilian Biomass Power Generation: Request for Proposals (RFP) to the Equipment Development Contractors: Gasifier/Gas Cleanup System - Gas Turbine System; Biomass Integrated Gasification/Gas Turbine (BIG/GT) Technology Demonstration.

Clinton, President W.J., Gore, A., Jr., Vice President (February, 1993). Technology for America's Economic Growth, a New Direction to Build Economic Strength; Washington, D.C.

Corman, J.C. (1986). System analysis of simplified IGCC plants. Report prepared for the US Department of Energy by General Electric Co., Corporate R\&D, Schenectady, New York.

DK-Teknik (April, 1991). Heat and Power Production from Straw, Wood and Other Biofuels in Denmark; prepared for the 6th European Conference on Biomass for Energy, Industry and Environment, Athens, Greece.

DK-Teknik. Heat and Power Production from Straw; prepared for the Center of Biomass Technology, Denmark.

Donovan, C.T. (April, 1993). Emerging Biomass and Waste Fuel Issues: Key Federal and State Policies and Regulations Affecting Wood Waste for Energy. Presented at the Strategic Benefits of Biomass and Waste Fuels Conference, Washington, D.C.

Dower, R.C., Zimmerman, M.B. (August, 1992), The Right Climate for Carbon Taxes: Creating Economic Incentives to Protect the Atmosphere, World Resources Institute.

Department of Energy, Electricity from Biomass: Renewable Energy Today and Tomorrow; Solar Thermal and Biomass Power Division, Office of Solar Energy Conversion, Washington, D.C.

Department of Energy (March, 1990), The Potential of Renewable Energy: An Interlaboratory White Paper; Office of Policy, Planning and Analysis.

Department of Energy (April, 1992), Electricity from Biomass: A Development Strategy, Solar Thermal and Biomass Power Division, Office of Solar Energy Conversion, Washington, D.C.

Department of Energy (1992), Electricity from Biomass: A Development Strategy, Solar Thermal and Biomass Power Division, Office of Solar Energy Conversion, Washington, D.C. 
Deparment of Energy (April, 1993), Electricity from Biomass: National Biomass Power Program FiveYear Plan (FY1994-FY1998); Solar Thermal and Biomass Power Division, Office of Solar Energy Conversion, Washington, D.C.

Engenharia, Brascep (March, 1992). Brazilian Biomass Power Generation: Phase I Final Report to the Global Environmental Facility; Biomass Integrated Gasification Gas Turbine (BIG/GT) Technology Demonstration.

Environmental Protection Agency (March, 1992). Renewable Electric Generation: An Assessment of Air Pollution Prevention Potential; Prepared by ICF Incorporated for Global Change Division, Office of Air and Radiation, Washington, D.C.

General Electric Company (1992). Biomass feedstock evaluations: Vermont program, Corporate R\&D, Schenectady, New York.

Gore, Senator A. (1992) Earth in the Balance: Ecology and the Human Spirit, Plume Printing.

Hart, F.C. (May, 1983). State-of-the-Art Survey of Wood Gasification Technology; Electric Power Research Institute.

Larson, E.D. and Williams, R.H. (1987). "Steam-injected gas turbines." Journal of Engineering for Gas Turbines and Power; 109(1):55-63.

Johansson, T.B., Kelly, H., Reddy, A.K., Williams, R.H. (1992). Renewable Energy: Sources for Fuels and Electricity, Island Press, Washington, D.C.

Kosmo, M. (October, 1987). Money to Burn? The High Costs of Energy Subsidies, World Resources Institute.

Miller, A.S., Mintzer, I.M., Hoagland, S.H. (April, 1986), Growing Power: Bioenergy for Development and Industry, World Resources Institute.

Munasinghe, M. (1990). Energy Analysis and Policy: Selected Works, IRPC.

National Independent Energy Producers (September, 1992), Energy for the Future, Negotiating Risk: Efficiency and Risk Sharing in Electric Power Markets.

National Wood Energy Association (1990). National bio-mass facilities directory, National Wood Energy Association, Arlington, Virginia.

Ogden, J.M., Williams, R.H., Fulmer, M.E. (1990). "Cogeneration Applications of Biomass Gasifier/Gas Turbine Technologies in the Cane Sugar and Alcohol Industries: Getting Started with Bioenergy Strategies for Reducing Greenhouse Gas Emissions." Prepared for the Program for Acceleration of Commercial Energy Research (PACER) Conference, New Delhi, India, April, 1990. Center for Energy and Environmental Studies, Princeton University, Princeton, New Jersey.

Paisley, M.A., Feldmann, H.F., Wood Gasification Combined Cycle Retrofit in a Conventional Pulp Mill Cogeneration System. 
Paisley, M.A., Feldmann, H.F., Appelbaum, H.R. (February, 1984). Initial Operation of the BattelleColumbus Biomass Gasification 12 Ton Per Day Process Research Unit; prepared for the 7th Annual Conference and Exhibition, New Orleans, Louisiana.

Paisley, M.A., Feldmann, H.F., Appelbaum, H.R. (November, 1984). Development of a High Throughput Gasifier to Produce a Medium BTU Gas From Wood; prepared for the Southeastern Regional Biomass Symposium, Atlanta, Georgia.

Paisley, M.A., Litt, R.D., Creamer, K.S. (February, 1990). Gasification of Refuse-Derived Fuel in a High Throughput Gasification System; prepared for the Energy from Biomass and Wastes XIV Conference, Lake Buena Vista, Florida.

Paisley, M.A., Breault, R.W., Bain, R. (October, 1992). Design and Economics of Electricity Production from an Indirectly Heated Biomass Gasifier; prepared for the Fifth Annual National Biofuels Conference and Exhibition: Waste Wood Processing and Combustion for Energy Newton, Massachusetts.

Schramm, G., Warford, J.J. (1989). Environmental Management and Economic Development, published for The World Bank, The John Hopkins University Press, Baltimore and London.

SERBEP Update (March, 1993). Planning for the Future.

Shell Briefing Service (1990). Focus on Forestry, Shell International Petroleum Co., London.

Tumbull, J. (January, 1993). Strategies for Achieving a Sustainable Clean and Cost-Effective Biomass Resource; Prepared for the Electric Power Research Institute.

Westinghouse Emerging Technologies. Powering the Future with Biomass Energy.

Williams, R.H. and Larson, E.D. (1989). "Electricity: efficient end-use and new generation technologies and their planning implications." 503-553, Lund University Press, Lund, Sweden.

World Bank, The (1992). World Development Report 1992: Development and the Environment, Executive Summary, Washington, D.C.

World Bank, The, Environmental Assessment Sourcebook, Volume I: Policies, Procedures, and CrossSectoral Issues, by the Environment Department, Washington, D.C.

World Resources Institute (1990). World resources 1990-91, Oxford University Press, New York. 


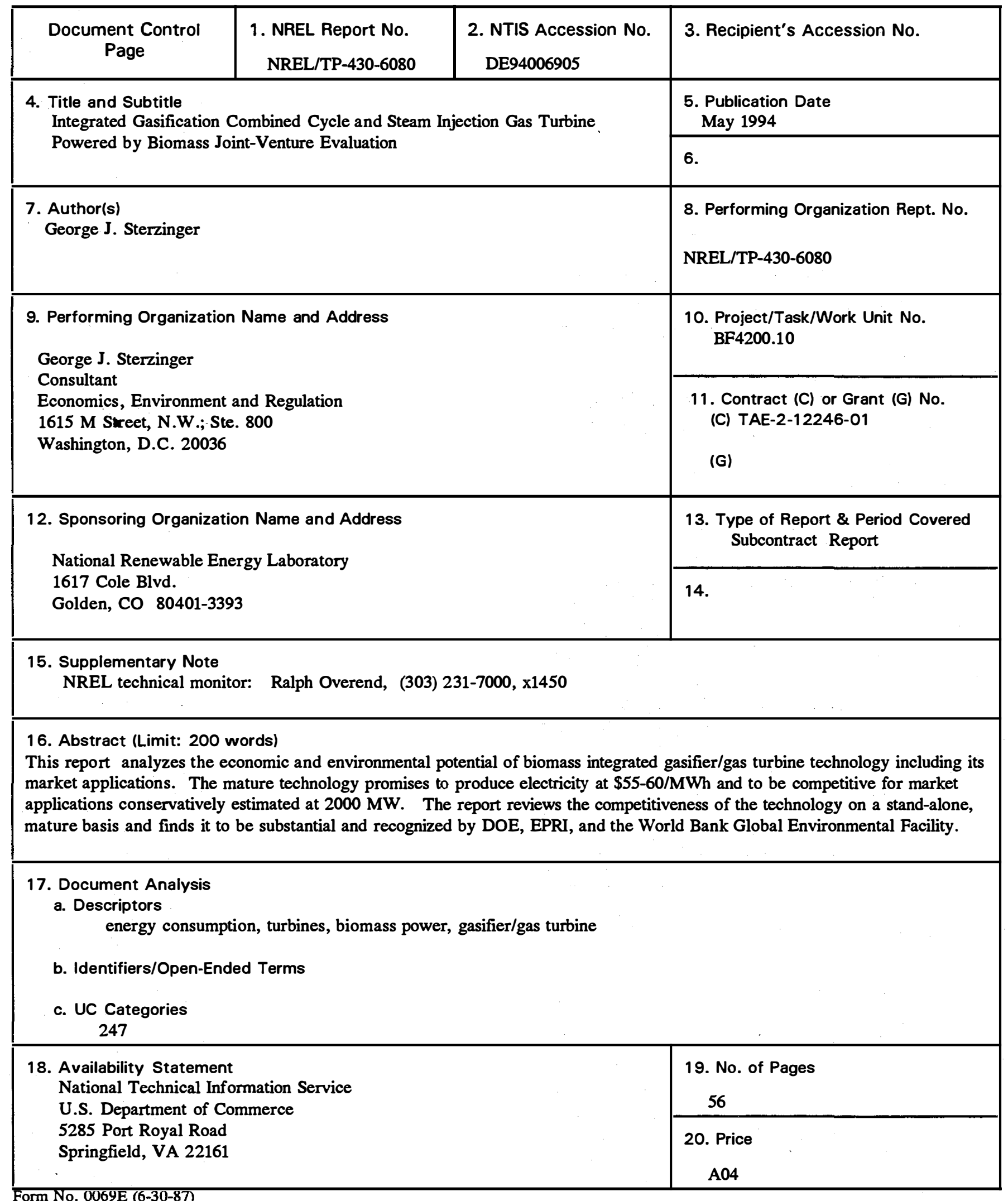

